\title{
A Case Study: How Students in a Small Rural West Virginia County Spend Their Out of School Time
}

Veronica R. Wilcox

West Virginia University

Follow this and additional works at: https://researchrepository.wvu.edu/etd

\section{Recommended Citation}

Wilcox, Veronica R., "A Case Study: How Students in a Small Rural West Virginia County Spend Their Out of School Time" (2012). Graduate Theses, Dissertations, and Problem Reports. 3525.

https://researchrepository.wvu.edu/etd/3525

This Thesis is protected by copyright and/or related rights. It has been brought to you by the The Research Repository @ WVU with permission from the rights-holder(s). You are free to use this Thesis in any way that is permitted by the copyright and related rights legislation that applies to your use. For other uses you must obtain permission from the rights-holder(s) directly, unless additional rights are indicated by a Creative Commons license in the record and/ or on the work itself. This Thesis has been accepted for inclusion in WVU Graduate Theses, Dissertations, and Problem Reports collection by an authorized administrator of The Research Repository @ WVU. For more information, please contact researchrepository@mail.wvu.edu. 
A Case Study: How Students in a Small Rural West Virginia County Spend Their Out of School Time

Veronica R. Wilcox

Thesis submitted to

Davis College of Agriculture, Natural Resources and Design at West Virginia University in partial fulfillment of the requirements

for the degree of

Master of Science

in

Agricultural and Extension Education

Deborah A. Boone, Ph.D., Chair

Harry N. Boone, Jr., Ph.D.

Jean M. Woloshuk, Ed.D.

Division of Resource Management

Morgantown, West Virginia

2012

Keywords: Out of School Time Study, Extension, Education, Positive Youth Development, Developmental Assets, Rural Youth, Appalachia 


\begin{abstract}
A Case Study: How Students in a Small Rural West Virginia County Spend Their Out of School Time
\end{abstract}

Veronica R. Wilcox

How youth spend their Out of School Time (OST) has a significant impact on their development. Youth get developmental assets from an integration of home, family, school, church, friends, neighbors, community, activities, and positive youth development programs - there are numerous inputs outside of school. Knowing how they spend their Out of School Time will allow the discovery of ways to improve youth development. A case study of all fifth, seventh, and ninth graders in a small rural West Virginia county was conducted using a questionnaire to determine how they spent their Out of School Time. Youth were asked about time spent in Out of School Time activities, developmental assets, and demographic characteristics. The study found a majority of the respondents reported they spent time in arts and music, playing or assisting with sports, attending religious services, being physically active, and spending four to nine hours a week hanging out with friends, and watching one to six hours per week watching television. A majority of the respondents reported no community service hours in the past year. The majority of respondents reported they meet new people easily, were good at making friends, cared about other people's feelings, and felt sad when a friend was unhappy. 


\section{DEDICATION}

To a valued friend and esteemed mentor, William E. Beckley, who recognized my potential; always encouraged educational opportunities to hone my skills and expand my horizons; was often a voice of reason, insight, humor, and a logical sounding board; and set me on the path of realizing my Extension career goals and dreams. To Dave Snively for reminding me that the world gets saved one step at a time. 


\section{ACKNOWLEDGEMENTS}

The committee for this project, consisting of Deborah A. Boone, Ph.D., Harry N. Boone, Jr., Ph.D., and Jean M. Woloshuk, Ed.D., all of whom are with WVU, who were thoughtful, insightful, encouraging, supporting, dedicated, and determined revisionists throughout this project. A special thanks goes to Dr. Debby Boone, who went well beyond the duties of an advisor, committee member, and teacher throughout the process.

Thanks to Phil Martin for his help setting up the database and keying data and to Harry N. Boone, Jr. Ph. D for his help analyzing the data. Thanks to Robin Daquillante and the Tyler County Board of Education for allowing the survey to be administered in the schools.

Previous researchers who shared their works, unabashed thoughts and suggestions: Kirk Astroth, Ph.D., Director of Arizona 4-H Youth Development; Jeff Goodwin, Ph.D., Director of Colorado 4-H Youth Development; and Frank Hodnett, Ph.D., Director of New Mexico 4-H Youth Development. 


\section{TABLE OF CONTENTS}

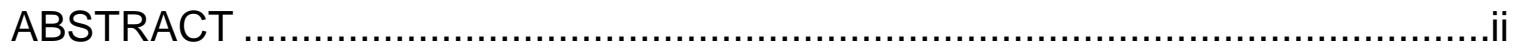

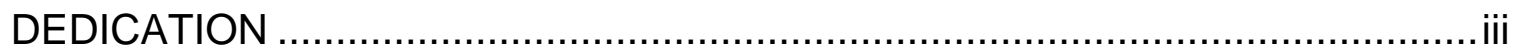

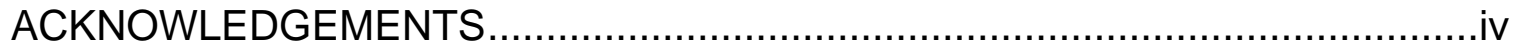

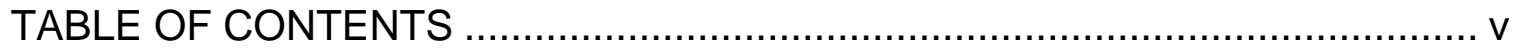

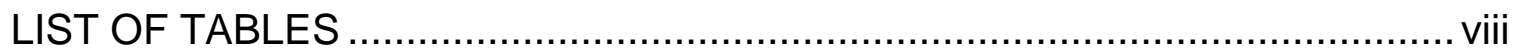

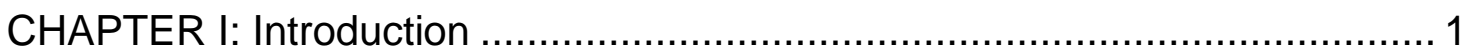

Problem Statement $\ldots \ldots \ldots \ldots \ldots \ldots \ldots \ldots \ldots \ldots \ldots \ldots \ldots \ldots \ldots \ldots \ldots \ldots \ldots \ldots \ldots \ldots \ldots \ldots . .3$

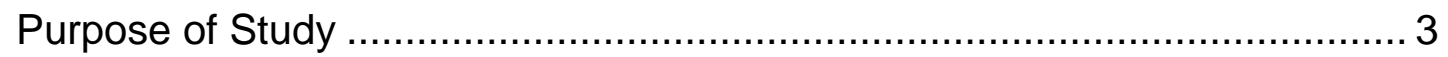

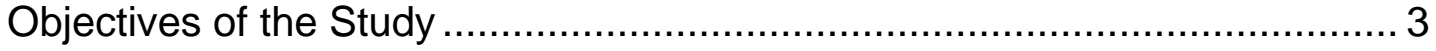

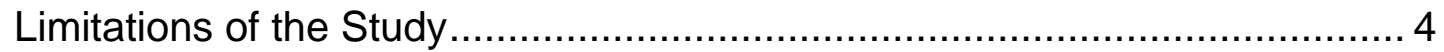

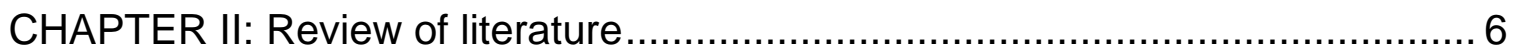

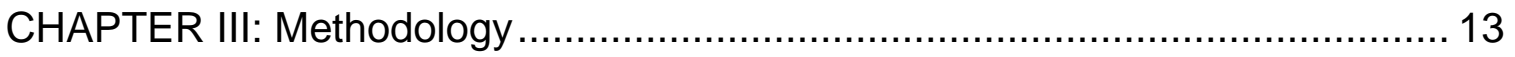

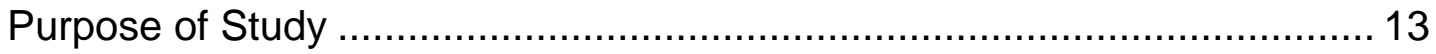

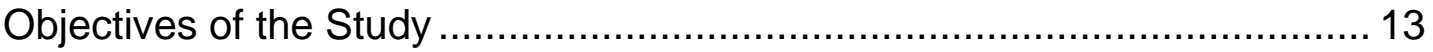

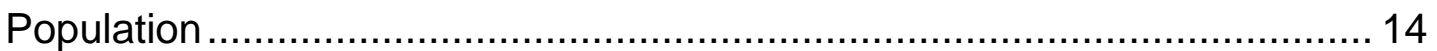

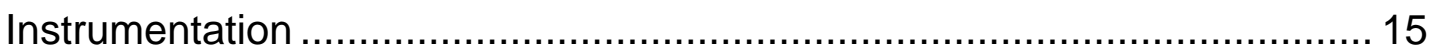

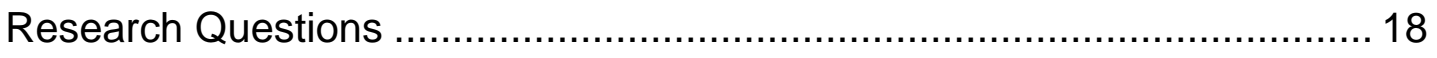

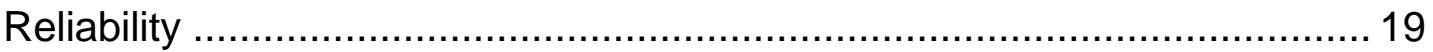

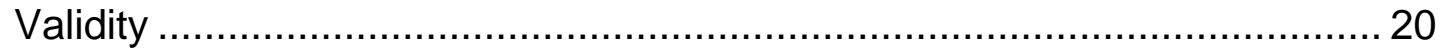




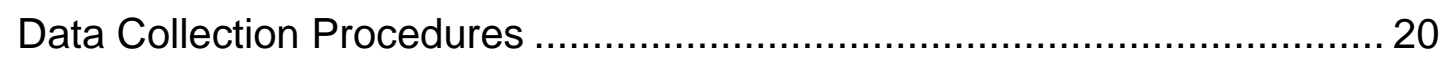

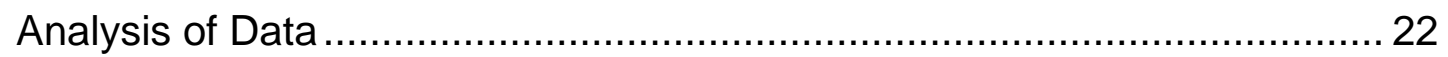

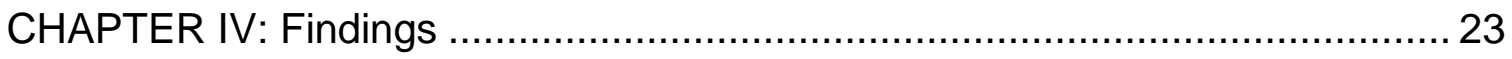

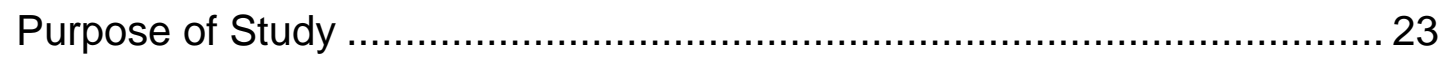

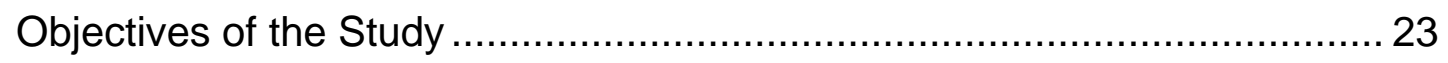

Demographic Characteristics of Respondents ......................................... 24

CHAPTER V: Summary, Conclusions, and Recommendations ...................... 57

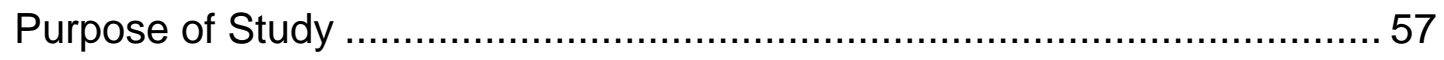

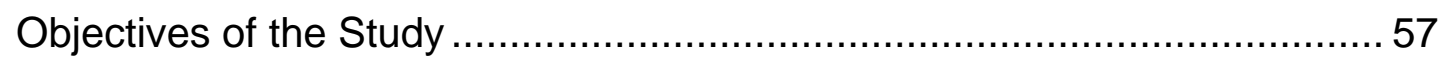

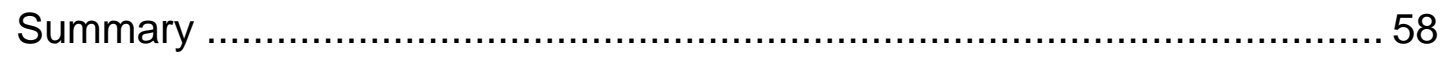

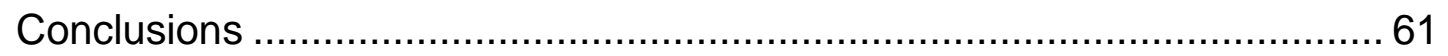

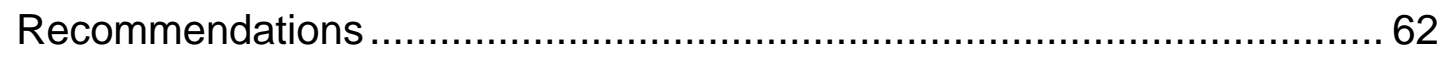

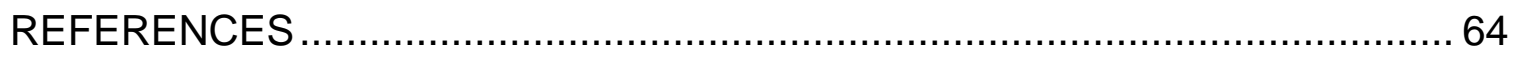

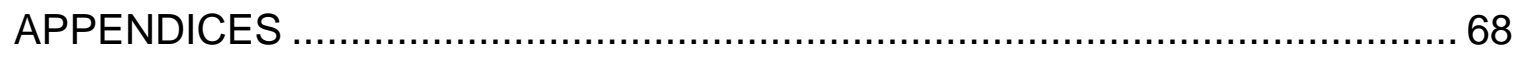

APPENDIX A: Permission Letter from School Superintendent ......................... 69

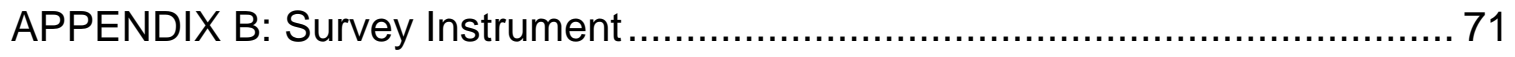

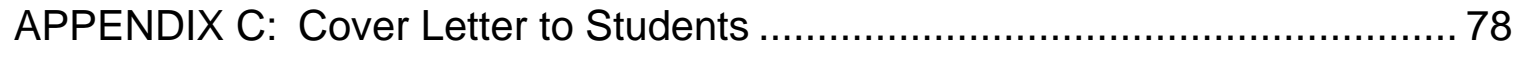

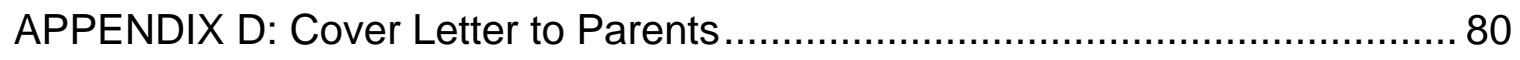

APPENDIX E: Instructions to Student and Parents ..................................... 82

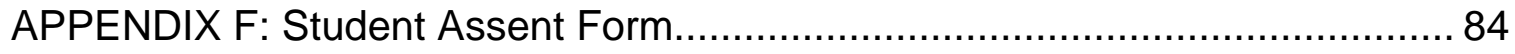




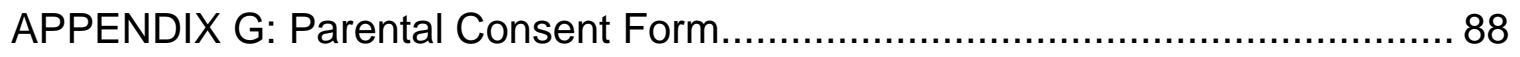

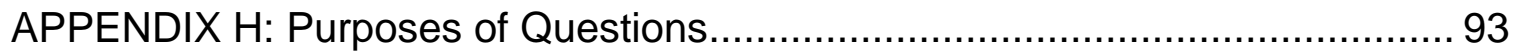

APPENDIX I: Out of School Time Survey Responses to Questions ................. 97

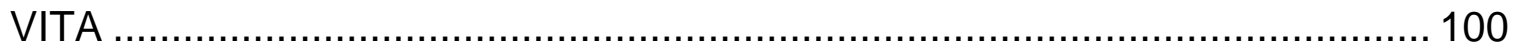




\section{LIST OF TABLES}

Table 1: Demographic Characteristics of Respondents................................. 25

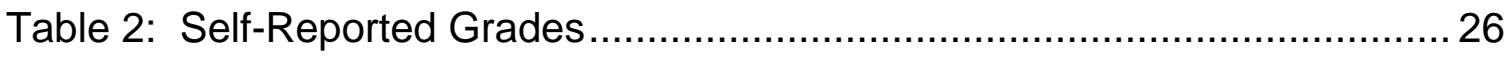

Table 3: Structured Hours Per Week Spent in Out of School Time Activities .... 29

Table 4: Unstructured Hours Per Week Spent in Out of School Activities ......... 31

Table 5: Community Service Hours Spent in the Last 12 Months..................... 33

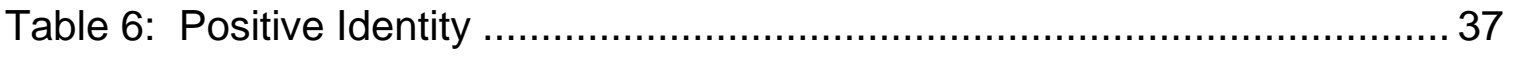

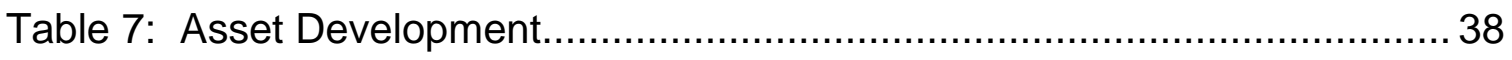

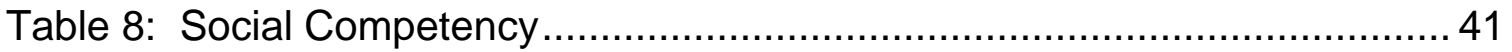

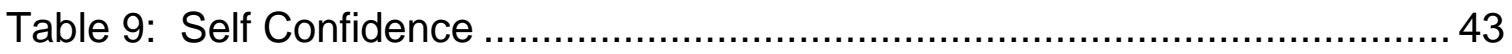

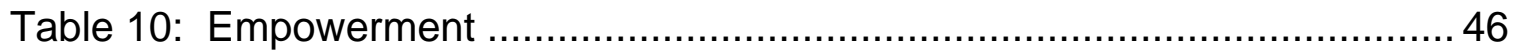

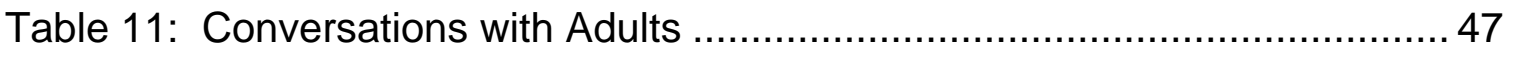

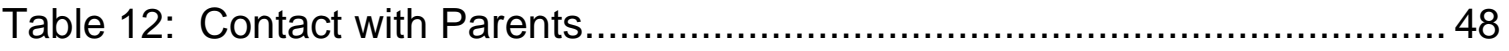

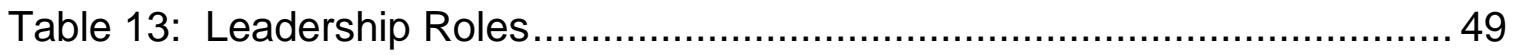

Table 14: 4-H Membership Ever ............................................................. 49

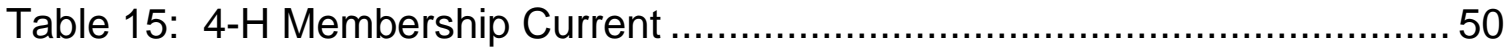

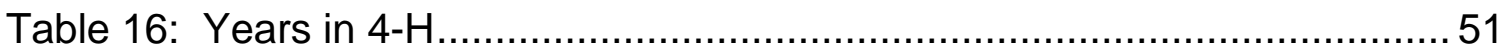

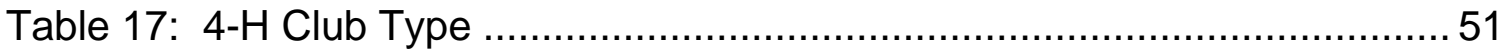

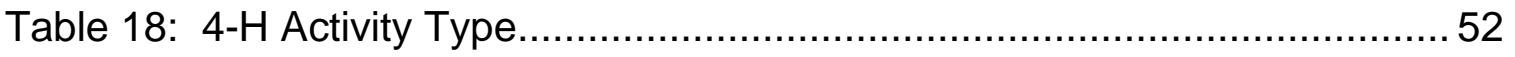

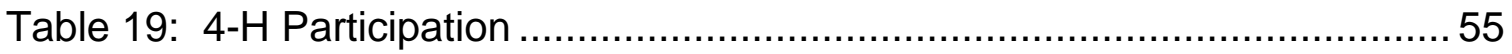




\section{CHAPTER I}

\section{Introduction}

Giving children what they need is about more than an education, it is about providing an asset rich environment in which to grow. The United States is the only Western nation without a national youth policy (Scales \& Leffert, 1999). Over the past 15 years, the focus of youth development has changed from one of treating problems after the fact to one of providing positive youth development through an asset rich environment. The more assets possessed by youth, the less probability of their engagement of problem behaviors and the greater likelihood that health and positive behaviors will characterize their development (Scales \& Leffert, 1999).

How youth spend their Out of School Time (OST) has a significant impact on their development. Youth get developmental assets from an integration of home, family, school, church, friends, neighbors, community, activities, and positive youth development programs - there are numerous inputs outside of school.

Providing developmental assets can predict seven thriving indicators in adolescents including: school success, leadership, valuing diversity, physical health, helping others, delay of gratification, and overcoming adversity (Scales, Benson, Leffert \& Blyth, 2000). However, the average adolescent in the United States has fewer than half of the 40 developmental assets as defined by Scales \& Leffert (1999). 
A child with an asset rich environment does not tend to have major issues and does not participate in as many risky behaviors as a child in an asset poor environment. The U.S. Department of Education found that "quality after-school programs keep kids out of trouble, prevent crime, juvenile delinquency, school vandalism, and violent victimization" (1998). Major issues with youth exist outside of an asset rich environment making them more vulnerable to risky behaviors. There is an inverse correlation; the fewer developmental assets that youth possess, the more likely they are to engage in high risk behavior (Scales \& Leffert, 1994).

Many communities are failing to provide assets (Benson, 1990, 1997), at which point other organizations must provide the beneficial developmental assets. $4-\mathrm{H}$ is one such program that provides development of positive assets, which can reduce risks and major issues. Studies in Montana (Astroth \& Haynes, 2001), Idaho (Goodwin, Barnett, Pike, Peutz, Lanting, \& Ward, 2005), Utah, Colorado (Goodwin, Carroll \& Oliver, 2007), Nevada (Singletary \& Smith, 2004), and New Mexico showed 4-H Members are more likely to: hold leadership positions; report higher rates of helping others and volunteering; have higher feelings of character, self-confidence, and empowerment; to discuss important issues with their parents, receive better grades; and are less likely to report participating in risky behaviors (Eberhart, 2009). 


\section{Problem Statement}

Although it is reasonable to assume a West Virginia Out of School Time study would have results comparable to the other states who had conducted similar surveys, the problem is that too little evidence exists. Whether or not Out of School Time activities are accessible to youth, developing asset rich environments, increasing life skills, and enabling students to make better choices has not been studied in West Virginia. Information gained from the study could be used by youth development professionals, funders, and policy makers to make more informed decisions.

\section{Purpose of Study}

Research is needed to quantitatively demonstrate to stakeholders the effects of Out of School Time activities in West Virginia. Being able to demonstrate the impact of Out of School Time activities will enhance efforts to improve the programs and to secure additional funding sources.

The purpose of the study is to describe what Out of School Time activities youth participated in in rural West Virginia and to see if these activities correlate to increased life skills in youth. The study will also provide information needed to suggest areas for program improvement.

\section{Objectives of the Study}

The objectives are reflected in the following research questions:

1. How do youth in West Virginia spend Out of School Time? 
2. Do Out of School Time programs increase positive assets in youth?

3. Does the number of hours participating in Out of School Time activities affect the amount of developmental assets received?

4. Is there a correlation between assets received and the students' self-reported academic performance?

5. Is there a correlation between assets received and the students' leadership positions held?

6. Is there a correlation between assets received and the students' having a positive self-identity?

7. Is there a correlation between assets received and the students' level of empowerment?

8. Is there a correlation between assets received and the students' conversations with adults?

9. Is there a correlation between assets received and the students' contact with parents?

10. Is there a correlation between assets received and the students' self confidence?

11. Is there a correlation between assets received and the students' contributions to others and the community?

\section{Limitations of the Study}

The study was limited to fifth, seventh, and ninth graders in one rural county in West Virginia. 


\section{Definitions}

At-Risk

Used to identify those who have characteristics that may

hamper learning skills (i.e.: discipline problems) through no

fault of their own

Life Skills

Ability gained from experience which helps in events

encountered throughout everyday existence of life.

Out-of-school time Encompasses a wide range of time for young people that takes place before school, after school, on the weekends, and during the summer and other school breaks (Loosli, 2002) 


\section{CHAPTER II}

\section{Review of literature}

While parents, schools, and the community used to share in educating youth, today's youth may only have one parent, may be at home alone until the parent(s) get off work, and may not participate in community activities (Schlink, 2000). When the Afterschool Alliance did the America After 3 PM survey, they found $16 \%$ of $\mathrm{K}-12$ youth in West Virginia are responsible for caring for themselves, and spend an average of 6 hours per week unsupervised. Unsupervised time could be much better spent in supervised activities. Studies have shown that out-of-school hours are when youth are most at risk and parents should be concerned (U.S. Department of Education, 1998). Unsupervised youth are at significantly higher risk of truancy, stress, receiving poor grades, early experimentation with sex, and substance abuse. By providing youth with wellplanned, research-based activities that are supervised by caring adults, youth can be safe-guarded from many risky behaviors (Astroth and Haynes, 2002). Astroth and Haynes (2001) found that youth who had participated in 4-H for more than a year are less likely to shoplift or steal, smoke cigarettes, ride in a car with someone who has been drinking, or damage property for fun. Out of School Time spent in youth programs, religious institutions, and creative activities can be considered informal education (Dubas \& Snider, 1993; Leffert \& Herring, 1998).

According to the 2003 National Survey of Children's Health, 41\% of West Virginians live in rural areas. Rural areas tend to have higher poverty rates, lower funding levels that cause fewer resources to be available, lack of 
transportation and geographic isolation, and difficulty in obtaining and retaining quality staff (Harvard, 2011). Not enough adults and communities are committed to maximum optimization of youth development programs, as is shown through few youth having sufficient developmental assets (Scales \& Leffert, 1999). Increasing access to quality Out of School Time programs, could provide youth in rural areas with more resources and assets (Harvard, 2011).

In the Kids Count Databook 2011, states are ranked on 10 measures through indicators including low birth weight babies, infant mortality rate, child and teen death rates, teen birth rates, teens not in school and not high school graduates, teens not attending school and not working, children living in families, where no parent has full-time, year-round employment, children in poverty, and children in single-parent families. West Virginia ranked 44 of 50 states.

The National Center for Research on Evaluation, Standards, and Student Teaching (CRESST) researched and identified 13 indicators of quality afterschool programs. CRESST found that quality afterschool programs develop an asset rich environment through goals for content-area practice. They develop links between content and school day activities and align the content materials with state standards. They provide a positive program environment employing motivational strategies to engage learning and promoting student engagement. They use research-based activities to achieve goals utilizing research-based curriculum and teaching strategies. The programs provide effective program management with ongoing evaluation, assessing program effectiveness, reviewing student progress, and resetting goals according to assessment results 
(Hange, 2009). Providing youth with quality out of school programs have shown increased academic achievement, communication, self-esteem, physical health, family functioning, job and leadership skills, and improved behavior, while decreasing school discipline, drug use, and behavior problems (Harvard, 2011).

Providing an asset rich environment helps ensure a more positive future for youth today, although only $42 \%$ of youth have $11-20$ of the 40 developmental assets. Studies indicate that 31 or more assets would be an appropriate benchmark, but less than eight percent of youth attain that mark (Jones, Ashurst, Kurzynske, 2007). Youth with 31-40 assets have a six percent or less chance of having problems with alcohol use, violence, illicit drug use, or sexual activity; while youth with $11-20$ assets have an $18-38 \%$ chance of experiencing problems in those same areas. Conversely, youth with $31-40$ assets have an $87-89 \%$ chance of exhibiting leadership, maintaining good health, and valuing diversity; while those with $11-20$ assets have a $48-66 \%$ chance of exhibiting those same skills (Search Institute, 2003). The eight categories of the developmental assets are divided between external: support, empowerment, boundaries and expectations, constructive use of time; and internal: commitment to learning, positive values, social competencies, and positive identity (Scales \& Leffert, 1999).

Even though a program focuses efforts on a deficit or problems a youth may exhibit, does not mean that eradicating the problem will prepare them for healthy development (Pittman \& Wright, 1991; Lerner, Fisher, \& Weinberg, 2000). Preventing problem behaviors through positive youth development 
programs could result in reducing prison populations and creating positive community contributors at the same time. Spending on corrections has increased three times faster than spending on education in the last 30 years (Lyons \& Walsh, 2010). According to the Children's Defense Fund 2011 WV, the average annual cost to house an inmate in $\mathrm{WV}$ is $\$ 35,725$, while the annual expenditure per public school pupil is only $\$ 9,440$. Rather than expending money to imprison people after committing crimes, investments should be made in providing youth asset rich environments in positive youth development through Out of School Time activities (Lyons \& Walsh, 2010). If youth do not have sufficient numbers of the assets, then more adults and communities need to commit to doing all they can to promote positive youth development (Scales \& Leffert, 1999). "The positive youth development approach aims at understanding, educating, and engaging children in productive activities rather than at correcting, curing or treating them for maladaptive tendencies or so-called disabilities" (Damon, 2004, p.15).

Even though the United States is the only western country without a national youth policy, it does have one nationally funded youth development program, 4-H, which is the largest youth program in the country (Scales \& Leffert, 1999). Astroth and Haynes (2001) conducted an Out of School Time/4-H Impact Study to determine fifth, seventh, and ninth grade students' perceptions of their own development and the impact 4-H may have. They sought to provide a more reliable method of evaluation to measure the impact of $4-\mathrm{H}$ in Montana. Astroth and Haynes (2001) found that $83 \%$ of all respondents in Montana were involved 
in Out of School Time activities. Of the non-4-H respondents, $48 \%$ were involved in a project to help others, $41 \%$ helped the poor, sick or others, $52 \%$ gave time or money to charity, and $74 \%$ helped others in school.

The study was replicated by Goodwin, Barnett, Pike, Peutz, Lanting, \& Ward (2005) in Idaho, with some modification. The Idaho study found that $38 \%$ of the non-4-H respondents indicated they had much to be proud of, $40 \%$ of their lives had purpose, and $42 \%$ volunteered in class. Fifty-nine percent felt they met new people easily, while $48 \%$ felt other kids looked up to them and followed their example. Sixty-seven percent of non-4-H respondents felt they could stay away from people who might get them in trouble and $84 \%$ knew how to say no when someone threatened their well-being (Goodwin, Barnett, Pike, Peutz, Lanting, \& Ward, 2005).

A Colorado 4-H Impact study was conducted by Goodwin, Carroll, and Oliver (2007) to provide sound, research-based information to the public about the effect of 4-H Youth Development membership on the lives of young people. In Colorado, Goodwin, Carroll, and Oliver (2007) found that $40 \%$ of the non $4-\mathrm{H}$ respondents felt their lives had purpose, 33\% had much to be proud of, 34\% volunteered in class, and 58\% met new people easily. Forty percent felt other kids looked up to them, $40 \%$ felt other kids followed their example, while $60 \%$ stayed away from people who might get them in trouble, and $79 \%$ knew how to say no when someone threatened their well-being.

Seevers, Hodnett, and Van Leeuwen (2011) replicated the study in New Mexico, where they found $4-\mathrm{H}$ members demonstrating they were much less 
likely to engage in risky behaviors. In New Mexico, $40 \%$ of non $4-\mathrm{H}$ respondents felt their lives had purpose and 39\% felt they had much to be proud of. Forty percent indicated that adults in their community made them feel important and $34 \%$ felt adults in their community listened to what they had to say. Fifty-one percent of non 4-H respondents felt adults in their hometown cared about people their age and 57\% felt they mattered to people in their hometown (Seevers, Hodnett, \& Van Leeuwen, 2011).

Similar studies have been conducted in Texas (Howard, 2001), Utah (Lee, Beard, \& Straquadine, 2003), Nevada (Singletary \& Smith, 2004), and Ohio (Lewis, 2008). In the Utah study, Lee, Beard and Straquadine (2003) found 62\% of non $4-\mathrm{H}$ respondents felt their lives had no purpose an 33\% felt they had much to be proud of. Of the non $4-\mathrm{H}$ respondents, $30 \%$ felt like they mattered to people in their hometown, $44 \%$ felt adults in their hometown cared about people their age, 53\% felt adults in their community listened to what they had to say, while $62 \%$ felt adults in their community made them feel important (Lee, Beard, \& Straquadine, 2003).

In an Ohio study by Lewis (2008), 24\% of the non $4-\mathrm{H}$ respondents indicated their lives had purpose and $20 \%$ had much to be proud of. Forty percent responded that other youth followed their example, $41 \%$ volunteer in class, while $59 \%$ reported they meet new people easily. Fifty-eight percent indicated that adults in their community made them feel important, while $71 \%$ stayed away from people who might get them in trouble, and $85 \%$ knew how to say no when someone threatens their well-being (Lewis, 2008). 
A meta analysis of 4-H Impact Studies performed in six states in the western region concluded that $4-\mathrm{H}$ members were more likely to receive better grades, less likely to participate in risky behaviors, more likely to hold leadership positions, and have higher rates of volunteerism than their non-4-H counterparts (Eberhart, 2009). The only state that did not show a significant difference between 4-Hers and non-4-Hers was Utah, although 4-Hers still scored higher in most of the categories.

Over the past 15 years, research has shown that providing an asset rich environment to youth has a much more positive impact than trying to treat problem behaviors after the fact. A program focusing efforts on deficits youth may face does not mean that eliminating the problem will prepare the youth for healthy development (Pittman \& Wright, 1991, and Lerner, Fisher, \& Weinberg, 2000). It takes a combination of positive youth development and community development to incorporate developmental assets that will reduce risks (Perkins, Borden, \& Villarruel, 2001).

The question arises, would a study conducted in West Virginia yield similar results? Do Out of School Time activities in West Virginia develop assets and life skills while reducing risky behaviors? The ability to demonstrate the link between positive youth development and Out of School Time activities would allow utilization of the information in demonstrating effectiveness when securing additional funding. The results of this study would provide information for improving the access to and quality of Out of School Time activities provided in the community. 


\section{CHAPTER III}

\section{Methodology}

\section{Purpose of Study}

Research is needed to quantitatively demonstrate to stakeholders the effects of Out of School Time activities in West Virginia. Being able to demonstrate the impact of Out of School Time activities will enhance efforts to improve the programs and to secure additional funding sources.

The purpose of the study is to describe what Out of School Time activities youth participated in in rural West Virginia and to see if these activities correlate to increased life skills in youth. The study will also provide information needed to suggest areas for program improvement.

\section{Objectives of the Study}

The objectives are reflected in the following research questions:

1. How do youth in West Virginia spend Out of School Time?

2. Do Out of School Time programs increase positive assets in youth?

3. Does the number of hours participating in Out of School Time activities affect the amount of developmental assets received?

4. Is there a correlation between assets received and the students' self-reported academic performance?

5. Is there a correlation between assets received and the students' leadership positions held? 
6. Is there a correlation between assets received and the students' having a positive self-identity?

7. Is there a correlation between assets received and the students' level of empowerment?

8. Is there a correlation between assets received and the students' conversations with adults?

9. Is there a correlation between assets received and the students' contact with parents?

10. Is there a correlation between assets received and the students' self-confidence?

11. Is there a correlation between assets received and the students' contributions to others and the community?

\section{Population}

The research study is to determine fifth, seventh, and ninth grade students' perceptions of their development and the impact Out of School Time activities has had on them. The target population was all youth in West Virginia from nine to nineteen. West Virginia had 20,048 students in the fifth grade, 21,245 in the seventh grade, and 23,921 in the ninth grade during the $2010-2011$ school year. However, the accessible population was the fifth $(n=95)$, seventh $(n=115)$, and ninth graders $(n=105)$ in Tyler County schools (Tyler County Board of Education, 2011). A census was conducted of all accessible fifth, seventh, 
and ninth grade students in Tyler County, West Virginia during spring the 2011 2012 school year.

Sampling errors were controlled by conducting a census of all students in the fifth, seventh, and ninth grades in Tyler county. Frame errors and selection errors were controlled by distributing the survey to all students in the fifth, seventh, and ninth grade classrooms in the county. Measurement errors were controlled through clearly stated instructions and questions and reverse ordered questions. Response errors were controlled by participants being informed that their responses would be kept confidential, the instructions were clear, and the instrument was valid and reliable. Non-response error was handled by sending reminders home with all the students in the fifth, seventh, and ninth grades, and extending the deadline a week. The survey's release time was deliberately timed to avoid spring break and standardized testing dates in the spring.

\section{Instrumentation}

The West Virginia Out of School Time Study was patterned after the Astroth and Haynes study in Montana (Astroth \& Haynes, 2001), the Idaho 4-H Impact Study (Goodwin, Barnett, Pike, Peutz, Lanting, \& Ward, 2005); and the Colorado 4-H Impact Study (Goodwin, Carroll, \& Oliver, 2007). All students in the fifth, seventh, and ninth grades in Tyler County schools were surveyed using an 82 question survey instrument comprised of questions on extracurricular participation, positive identity, social competency, contact with adults, self 
confidence, community service, empowerment, caring about others, skills learned, demographics, and the impact of $4-\mathrm{H}$.

Other changes from the original studies included minor revisions recommended from those whom conducted previous studies, updating the survey to the most current survey standards (Dillman, Smyth, \& Christian, 2009), and calculating the hours spent during activities and community service rather than yes/no answers. Recommended changes to some of the original yes/no questions from the New Mexico, Idaho, Colorado, and Montana studies to frequencies, were made in order to obtain better data. The researcher added questions regarding time spent watching television, playing video games, and exercising based on a report that actively engaged youth devoted less afterschool time watching television (Vandell, Shernoff, Pierce, Bolt, Dadisman \& Brown, 2005).

Out of School Time structured activities included hours spent per week in music and the arts, playing on or helping with sports teams at school or in the community, in other school clubs or organizations, in 4-H club activities or projects, in clubs or organizations outside of school, and attending religious services. Out of School Time unstructured activities consisted of hours spent per week hanging out with friends, being physically active, watching television, and playing video games.

Community service included hours spent in the past 12 months involved in a service activity to help make life better for other individuals, to make life better for the community, and to make life better for the poor, hungry, sick or people 
unable to take care of themselves. Positive identity included doing things on their own, being comfortable giving a speech in front of others, having control over things that happen in their lives, liking themselves, being glad to be themselves, feeling they have much to be proud of, feeling their lives have purpose, not giving up when things do not go well, being responsible for their actions, being comfortable giving demonstrations in front of people, being a good organizer, being a good money manager, and having good record keeping skills.

Social competency included making friends, caring about other people's feelings, feeling sad when a friend is unhappy, volunteer in class to lead activities, meet new people easily, comfortable in new situations, good at planning ahead, feel other kids look up to them, feel other kids follow their example, are good a keeping friends, set goals, and think they will be happy in 10 years. Self confidence included staying away from people who might get them in trouble, knowing how to say no when someone wants them to do things they know are threatening to their well-being, finding a way to work through it when things do not go well, knowing how to say no when someone wants them to do things they know are wrong.

Empowerment consisted of adults in their community listen to what they have to say, feeling useful in their family, adults in their community make them feel important, adults in their home town care about people their age, they feel like they matter to people in their home town, they feel important in their family, students help decide what goes on at their school, they are given lots of chances to help make their town or community a better place to live. 
Conversation with adults included having a conversation with a parent or guardian within the last month that lasted 10 minutes or more, having a conversation with an adult other than a parent or guardian within the last month that lasted 10 minutes or more, and if there was an adult other than their parent or guardian to whom they would feel comfortable going to for help if they had an important question about their life. Contact with parents consisted of getting along with parents, consequences to breaking parents' rules, and parents give help and support when needed.

4-H activities included 4-H camp, 4-H Officers' Training, 4- $\mathrm{H}$ projects and fair exhibits, 4-H public speaking and presentations, 4-H judging events, 4-H skillathons, and other.

\section{Research Questions}

The research questions were replicated from previous studies. Some modifications were made to the instrument questions based on suggestions made by those whom conducted the previous studies. Other changes were made in the design of the instrument, so that it would follow Dillman's (2009) rules. The first and second section consisted of 13 frequency items. The third section consisted of three yes/no responses. The fourth section consisted of 40 statements with responses on a four point Likert scale. The fifth section included seven demographic questions. The last section asked about their participation in 4-H with two yes/no, one frequency, two check all that apply, 12 Likert items and two open ended questions. 


\section{Reliability}

Reliability of the instrument was established using the entire data set and the Statistical Package for Social Sciences' (SPSS). Survey questions were grouped according to overall categories of social competency, empowerment, skills learned, contact with parents, self confidence, community service, conversation with adults, Out of School Time structured and unstructured activities, and 4-H activities.

Cronbach Alpha levels were calculated for the constructs of social competency, empowerment, and skills learned. The reliability of these sections was found to be extensive at $.76, .78$, and .72 respectively (Robinson, Shaver, \& Wrightsman, 1991). Contact with parents was found to be minimal at .60 (Robinson, Shaver \& Wrightsman, 1991). The Out of School Time structured activities tested were found to be .178 , making reliability of that section moderate (Robinson, Shaver \& Wrightsman, 1991).

The self confidence, out school time unstructured activities, community service, and conversation with adults sections were tested for reliability using the split-half statistic coefficient. The equal-length SpearmanBrown value was found to be $.448, .509, .680$, and .520 respectively making reliability of these sections exemplary Robinson, Shaver \& Wrightsman, 1991). The 4-H section was tested for reliability using the split-half statistic coefficient. The equal-length Spearman-Brown value was found to be .905 for the instrument, making reliability of the instrument exemplary (Robinson, Shaver \& Wrightsman, 1991). The instrument was established to be reliable. 


\section{Validity}

The instrument was presented to a panel of experts to establish its content and face validity. The panel consisted of teacher educators in Agricultural and Extension Education at West Virginia University and West Virginia University Extension 4-H Youth Specialist. Each one of these individuals has had extensive teaching and/or Extension field experience. They possessed many leadership skills and have extensive experience in research design. The panel of experts concluded that the instrument had content and face validity.

\section{Data Collection Procedures}

The researcher contacted the school superintendent and Board of Education and obtained permission to implement the surveys (see Appendix A). The packets were divided by class and grade for each school. Packets including the surveys (see Appendix B), cover letter to the student (see Appendix C), cover letter to the parents (see Appendix D), instructions (see Appendix E), assent forms (see Appendix F), consent forms (see Appendix G), and were taken to each school in the county with fifth, seventh, and ninth grade classes. The students were asked to take the packet home to have their parents sign the consent form and they were to sign the assent form and return the surveys to the teacher. When each student completed and returned the survey, the teacher bundled that class's surveys together. The researcher gathered the surveys labeled by school and grade for compilation. 
Non-response rate was a concern, so reminders were sent home with all the students in the fifth, seventh, and ninth grades. The deadline was extended a week to get more responses. The survey's release time was deliberately timed to avoid spring break and standardized testing times.

The survey format consisted of frequency, yes/no, Likert scale, multiple choice, fill in the blank and essay questions (Dillman, Smyth, \& Christian, 2009). The questionnaires were distributed and collected by the classroom teachers, who bundled their class's surveys together. The researcher collected the surveys from the teachers and bundled them together by classroom, grade, and school. The surveys were coded afterward by numbering the matching assent, consent, and surveys for data entry purposes.

The data were analyzed using the Statistical Package for the Social Sciences (SPSS version 15). Descriptive statistics were used to analyze the data. The rankings of the Likert-scale items were converted to numerical categories and treated as interval level data with $1=$ strongly agree, $2=$ agree, 3 $=$ disagree, and $4=$ strongly disagree. Some questions were written in an opposite scale to discourage set response patterns. Opposite scale items were reverse coded for analysis.

Missing data were coded as nine for data entry, then deleted from statistical analysis. Descriptive statistics of frequencies and percentages were calculated. 


\section{Analysis of Data}

Three hundred and fifteen surveys were distributed to all fifth, seventh, and ninth grades in Tyler County, West Virginia. Seventy-six questionnaires were returned, while eight participants who returned surveys declined to participate in the study. None of the questionnaires were unusable due to incorrect completion of the survey. The response rate was 24 percent, with 22 percent of the survey's completed and useable. 


\section{CHAPTER IV}

\section{Findings}

\section{Purpose of Study}

Research is needed to quantitatively demonstrate to stakeholders the effects of Out of School Time activities in West Virginia. Being able to demonstrate the impact of Out of School Time activities will enhance efforts to improve the programs and to secure additional funding sources.

The purpose of the study is to describe what Out of School Time activities youth participated in in rural West Virginia and to see if these activities correlate to increased life skills in youth. The study will also provide information needed to suggest areas for program improvement.

\section{Objectives of the Study}

The objectives are reflected in the following research questions:

1. How do youth in West Virginia spend Out of School Time?

2. Do Out of School Time programs increase positive assets in youth?

3. Does the number of hours participating in Out of School Time activities affect the amount of developmental assets received?

4. Is there a correlation between assets received and the students' self-reported academic performance?

5. Is there a correlation between assets received and the students' leadership positions held? 
6. Is there a correlation between assets received and the students' having a positive self-identity?

7. Is there a correlation between assets received and the students' level of empowerment?

8. Is there a correlation between assets received and the students' conversations with adults?

9. Is there a correlation between assets received and the students' contact with parents?

10. Is there a correlation between assets received and the students' self-confidence?

11. Is there a correlation between assets received and the students' contributions to others and the community?

\section{Demographic Characteristics of Respondents}

Forty-two of the respondents were female (62.7\%), while 25 (37.3\%) were male. The mode for gender was female (see Table 1).

Of the respondents, 32 were in the $12-13$ age category (47.8\%), being the median age. Twenty-six (38.8\%) listed their age as the 10-11 bracket. Nine (13.4\%) of the respondents identified their age to be in the 14-15 year category.

Thirty-one of the respondents (46.3\%) were in the seventh grade. Twenty-eight of the respondents (41.8\%) were in the fifth grade. There were eight respondents (11.9\%) in the ninth grade. 


\section{Table 1}

Demographic Characteristics of Respondents $(N=68)$

\begin{tabular}{|c|c|c|}
\hline & $f$ & $\%$ \\
\hline \multicolumn{3}{|l|}{ Gender } \\
\hline Male & 25 & 37.3 \\
\hline Female & 42 & 62.7 \\
\hline Missing & 1 & 1.5 \\
\hline \multicolumn{3}{|l|}{ Age } \\
\hline 8- 9 years old & 0 & 0.0 \\
\hline 10-11 years old & 26 & 38.8 \\
\hline $12-13$ years old & 32 & 47.8 \\
\hline $14-15$ years old & 9 & 13.4 \\
\hline $16-17$ years old & 0 & 0.0 \\
\hline $18+$ years old & 0 & 0.0 \\
\hline Missing & 1 & 1.5 \\
\hline \multicolumn{3}{|l|}{ Grade Level of Respondents } \\
\hline 5th Grade & 28 & 41.8 \\
\hline 7th Grade & 31 & 46.3 \\
\hline 9th Grade & 8 & 11.9 \\
\hline Missing & 1 & 1.5 \\
\hline \multicolumn{3}{|l|}{ Residence Location } \\
\hline On a farm & 5 & 7.5 \\
\hline In country, not on a farm & 28 & 41.8 \\
\hline In town & 34 & 50.7 \\
\hline Missing & 1 & 1.5 \\
\hline
\end{tabular}


The mode for residence location was reported as in town by 34 respondents (50.7\%). Twenty-eight participants replied that they lived in the country, not on a farm (41.8\%) and five (7.5\%) lived on a farm. One person did not complete the demographic questions (see Table 1).

\section{Self-Reported Grades}

The mode and median grade category was A's and B's, with 29 of the participants (44.6\%) reporting receiving A's and B's. Fifteen students reported mostly A's (23.1\%), 14 reported receiving B's and C's (21.5\%), four participants reported mostly B's (6.2\%), two reported C's and D's (3.1\%), and 1 (1.5\%) reported mostly C's (see Table 2).

Table 2

Self-Reported Grades $(N=68)$

\begin{tabular}{lcc} 
& $f$ & $\%$ \\
\hline Mostly A's & 15 & 23.1 \\
A's and B's & 29 & 44.6 \\
Mostly B's & 4 & 6.2 \\
B's and C's & 14 & 21.5 \\
Mostly C's & 1 & 1.5 \\
C's and D's & 2 & 3.1 \\
Mostly D's & 0 & 0.0 \\
Mostly below D's & 0 & 0.0 \\
Missing & 1 & 1.5 \\
\hline
\end{tabular}




\section{Structured Hours Per Week Spent in Out of School Time Activities}

Twenty-nine (43.3\%) of students responded they spent one to three hours per week in the arts and music, which was the mode and median. Sixteen (23.9\%) students spent no time (23.9\%) in arts and music, while12 students (17.9\%) spent four to six hours, six (9\%) spent seven to nine hours, three (4.5\%) spent 14 plus hours, and one (1.5\%) spent 10-13 hours in arts and music (see Table 3).

Regarding time spent playing or helping with a sports team, 19 (27.9\%) responded they spent one to three hours per week, which was the mode and median. Eighteen students (26.5\%) spent no time with sports teams, 12 (17.6\%) spent four to six hours, $10(14.7 \%)$ spent 14 plus hours, six (8.8\%) spent 10 to 13 hours, and three (4.4\%) spent seven to nine hours with a sports team.

The mode and median was no time spent in other school clubs or organizations, with 47 respondents (70.1\%). Fifteen students (22.4\%) spent one to three hours per week, four (6\%) spent four to six hours, one spent 10 to 13 hours, and no respondents reported they spent more than 14 hours involved in other school clubs or organizations.

Fifty-nine students (88.1\%) didn't spend time participating in 4-H activities, which was the mode and median. Six students spent one to three hours a week,

one reported seven to nine hours (1.5\%), and one reported 14 plus hours in $4-\mathrm{H}$.

Fifty-seven participants (86.4\%) did not spend any time in clubs or organizations outside of school each week, which was the mode and mean. Seven (10.6\%) respondents spent one to three hours per week in clubs or 
organizations outside of school time, one respondent (1.5\%) spent four to six hours, one respondent (1.5\%) spent 10 to 13 hours, and no respondents seven to nine or 14 plus hours in out of school clubs or organizations.

Thirty-three (49.3\%) respondents spent one to three hours per week in religious services, while 25 (37.3\%) respondents did not spend time in religious services. Eight (11.9\%) participants spent four to six hours each week in religious services, one $(1.5 \%)$ reported 10 to 13 hours, and none of the respondents reported seven to nine or 14 or more hours per week in religious services (see Table 3).

\section{Unstructured Hours Per Week Spent in Out of School Time Activities}

When participants were asked how many hours per week they spend hanging out with friends, 22 (32.4\%) responded they spend four to six hours, 16 responded (23.5\%) with one to three hours, and 13 (19.1\%) responded with 14 or more hours. Twelve youth (17.6\%) reported hanging out with friends seven to nine hours per week, three participants (4.4\%) spent 10 to 13 hours, and two participants (2.9\%) did not spend time with friends. The mode and median was four to six hours per week that respondents spent hanging out with friends (see Table 4). 
Table 3

Structured Hours Per Week Spent in Out of School Time Activities $(N=68)$

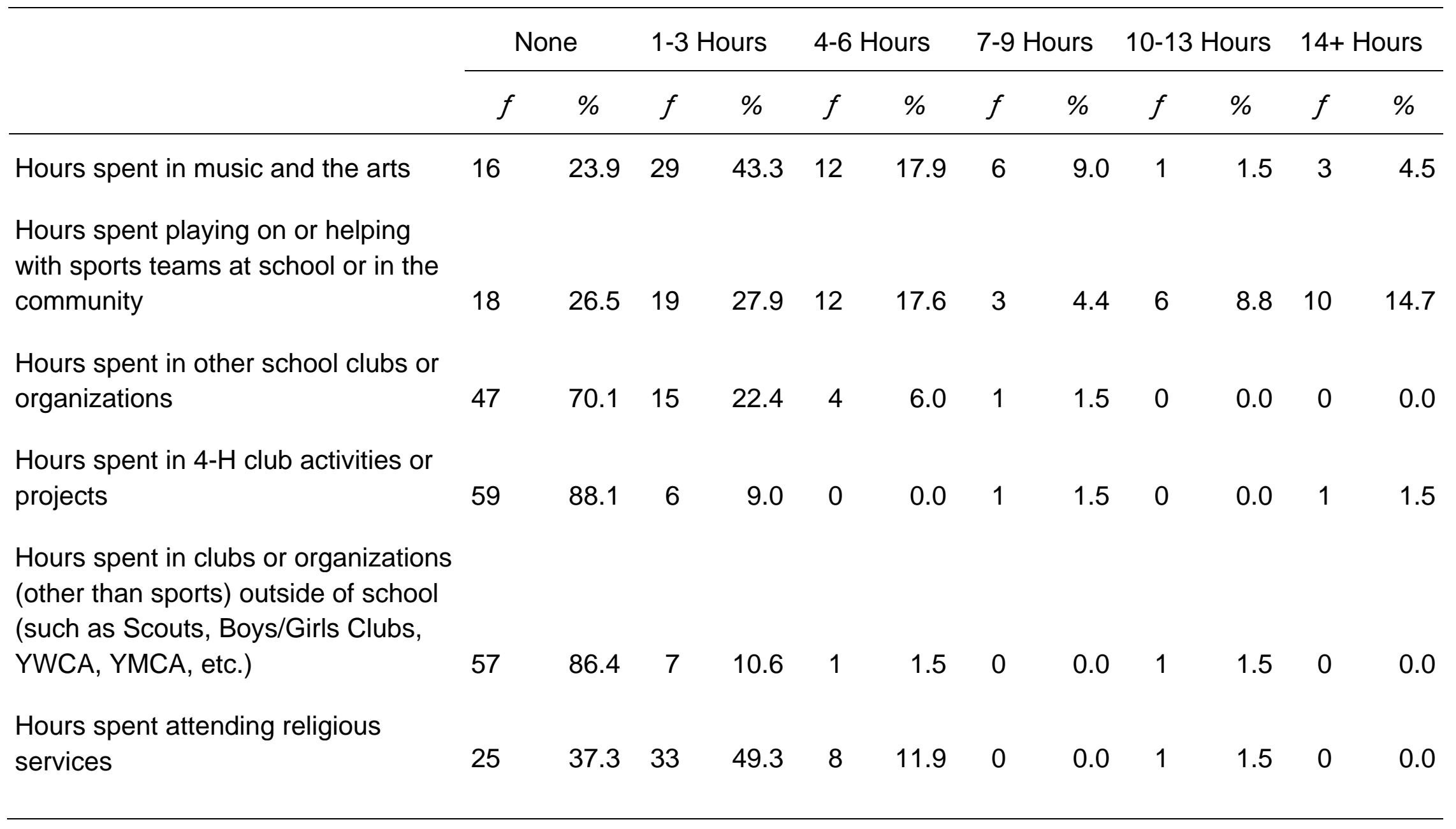


Twenty-three youth (33.8\%) reported being physically active four to six hours per week, $16(23.5 \%)$ reported 14 or more hours, and 10 students (14.7\%) reported seven to nine hours. Nine respondents (13.2\%) were physically active one to three hours and eight students (11.8\%) reported 10 to13 hours, while two (2.9\%) were not physically active. The mode and median for being physically active was four to six hours per week.

Time spent watching television varied from 26 (38.8\%) respondents watching one to three hours per week, 23 students (34.3\%) watching television four to six hours per week, and eight students (11.9\%) watching seven to nine hours, with two students (3.0\%) reporting they did not watch television. Four students (6.0\%) reported watching television10 to 13 hours per week and four students (6.0\%) reported watching television 14 hours or more. The mode for watching television was one to three hours, but the median was four to six hours.

Twenty-six students (38.2\%) reported they did not spend any time playing video games. Twenty-four respondents (35.3\%) played video games one to three hours per week, seven (10.3\%) played seven to nine hours, five $(7.4 \%)$ played four to six hours, four (5.9\%) played 14 or more hours, and two (2.9\%) played video games10 to 13 hours per week. The mode was no time spent playing video games; while the median was one to three hours (see Table 4). 
Table 4

Unstructured Hours Per Week Spent in Out of School Activities ( $N=68)$

\begin{tabular}{lrrrrrrrrrrrrr}
\hline & \multicolumn{3}{c}{ None } & \multicolumn{1}{c}{$1-3$ Hours } & $4-6$ & Hours & 7-9 Hours & 10-13 Hours & 14+ Hours \\
\cline { 2 - 13 } & $f$ & $\%$ & $f$ & $\%$ & $f$ & $\%$ & $f$ & $\%$ & $f$ & $\%$ & $f$ & $\%$ \\
\hline Hours spent hanging out with friends & 2 & 2.9 & 16 & 23.5 & 22 & 32.4 & 12 & 17.6 & 3 & 4.4 & 13 & 19.1 \\
Hours spent being physically active & 2 & 2.9 & 9 & 13.2 & 23 & 33.8 & 10 & 14.7 & 8 & 11.8 & 16 & 23.5 \\
Hours spent watching television & 2 & 3.0 & 26 & 38.8 & 23 & 34.3 & 8 & 11.9 & 4 & 6.0 & 4 & 6.0 \\
Hours spent playing video games & 26 & 38.2 & 24 & 35.3 & 5 & 7.4 & 7 & 10.3 & 2 & 2.9 & 4 & 5.9 \\
\hline
\end{tabular}




\section{Community Service Hours Spent in the Last 12 Months}

When participants were asked how many hours they spent during the last 12 months in service activities to make life better for other individuals, 42 (60.9\%) responded no time was spent, 20 (29\%) reported one to 10 hours, one (1.4\%) reported $11-20$ hours, five (7.2\%) reported $21-30$ hours, and no one reported more than 31 hours spent making life better for other individuals. The mode for service hours spent making life better for other individuals was none.

Time spent making life better for the community in the last 12 months was reported as 41 (59.4\%) responded no time was spent, 20 (29\%) reported one to 10 hours, four (5.8\%) reported 11-20 hours, one reported 31-40 hours, and one (1.4\%) reported 51 or more hours spent making life better for the community. The mode for service hours spent making life better for the community was none.

Time spent making life better for the poor, hungry, sick or people unable to take care of themselves in the last 12 months was reported by respondents as 36 (52.2\%) responded no time was spent, 24 (34.8\%) reported one to 10 hours, six (8.7\%) reported $11-20$ hours, one (1.4\%) reported $21-30$ hours, one (1.4\%) reported 31-40 hours, and no one reported 51 or more hours spent making life better for the community. The mode for service hours spent making life better for the poor, hungry, sick or people unable to take care of themselves was none (see Table 5). 
Table 5

Community Service Hours Spent in the Last 12 Months (N=68)

\begin{tabular}{|c|c|c|c|c|c|c|c|c|c|c|c|c|}
\hline & \multicolumn{2}{|c|}{ None } & \multicolumn{2}{|c|}{ 1-10 Hours } & \multicolumn{2}{|c|}{ 11-20 Hours } & \multicolumn{2}{|c|}{ 21-30 Hours } & \multicolumn{2}{|c|}{ 31-40 Hours } & \multicolumn{2}{|c|}{$51+$ Hours } \\
\hline & $f$ & $\%$ & $f$ & $\%$ & $f$ & $\%$ & $f$ & $\%$ & $f$ & $\%$ & $f$ & $\%$ \\
\hline To make life better for other individuals & 42 & 60.9 & 20 & 29.0 & 1 & 1.4 & 5 & 7.2 & 0 & 0.0 & 0 & 0.0 \\
\hline To make life better for the community & 41 & 59.4 & 20 & 29.0 & 4 & 5.8 & 0 & 0.0 & 1 & 1.4 & 1 & 1.4 \\
\hline $\begin{array}{l}\text { To make life better for the poor, } \\
\text { hungry, sick or people unable to take } \\
\text { care of themselves }\end{array}$ & 36 & 52.2 & 24 & 34.8 & 6 & 8.7 & 1 & 1.4 & 1 & 1.4 & 0 & 0.0 \\
\hline
\end{tabular}




\section{Positive Identity}

A composite score of the positive identity variables of: doing things on their own, being comfortable giving a speech in front of others, having control over things that happen in their lives, liking themselves, being glad to be themselves, feeling they have much to be proud of, feeling their lives have purpose, not giving up when things do not go well, being responsible for their actions, being comfortable giving demonstrations in front of people, being a good organizer, being a good money manager, and having good record keeping skills was used to create the mean. The mean for positive identity was 3.04 , with a standard deviation of .38 (see Table 7).

When students were asked if they could do things on their own, 31 (45.6\%) respondents strongly agreed and 31 (45.6\%) agreed. Six students disagreed and no respondent strongly disagreed. The median for positive identity was agreed (see Table 6).

Thirty-one (46.3\%) students agree they were comfortable giving speeches, while ten students (14.9\%) strongly agreed. Twenty (29.9\%) respondents disagreed that they felt comfortable giving speeches, while six (9.0\%) strongly disagreed. The median for being comfortable giving speeches was agreed.

Thirty-two youth (48.5\%) agreed that they had control over the things that happened in their lives, while 13 (19.7\%) strongly agreed. Fifteen students (22.7\%) disagreed and six strongly disagreed (9.1\%) that they had control over 
things in their lives. The median for having control over things that happened in their lives was agreed.

When asked if on the whole if they liked their selves, 27 (39.7\%) students agreed and 34 (50\%) students strongly agreed. Six students (8.8\%) disagreed with the statement and one (1.5\%) strongly disagreed. The median for liking themselves was agreed.

Twenty (29.9\%) respondents agreed and 41 respondents (61.2\%) strongly agreed and that they were glad to be themselves. Six students (8.8\%) disagreed and one (1.5\%) student strongly disagreed. The median for being glad to be themselves was strongly agreed.

Twenty-two students (32.4\%) agreed and 37 students (54.4\%) strongly agreed that they had much to be proud. Eight (11.8\%) respondents disagreed and one (1.5\%) strongly disagreed. The median for having much to be proud of was strongly agreed.

Thirty respondents (44.8\%) agreed and 22 students (49.3\%) strongly agreed and that their lives have purpose. Two students (3.0\%) disagreed and two (3.0\%) strongly disagreed. The median for their lives having purpose was agreed.

Thirty-three respondents (50\%) agreed that they do not give up when things do not go well and 17 (25.8\%) strongly agreed. Nine students (13.6\%) disagreed and seven (10.6\%) strongly disagreed. The median for not giving up when things do not go well was agreed. 
When students were asked if they are responsible for their own actions, 42 agreed (61.8\%) and 21 (30.9\%) strongly agreed. Two students (2.9\%) disagreed and three (4.4\%) strongly disagreed. The median for being responsible for their own actions was agreed.

Thirty students (44.8\%) agreed that they were comfortable giving a demonstration in front of others and 15 (22.4\%) strongly agreed. Fifteen students (22.4\%) disagreed and seven (10.4\%) strongly disagreed. The median was agreed.

Thirty-seven respondents (56.1\%) agreed and nine students (13.6\%) strongly agreed that they were good organizers. Sixteen (24.2\%) disagreed that they were good organizers, while four (6.1\%) strongly disagreed. The median for being good organizers was agreed.

Thirty-one students (47.7\%) agree they were good money managers, while $12(18.5 \%)$ strongly agreed. Eighteen (27.7\%) disagreed they were good money managers, while four (6.2\%) strongly disagreed. The median was agreed for being good money managers.

Thirty-two students (47.1\%) disagreed that they have good record keeping skills, while eight (11.8\%) strongly disagreed. Seventeen respondents (25\%) agreed that they have good record keeping skills, while 11 respondents (16.2\%) strongly agreed. The median for having good record keeping skills was disagreed (see Table 6). 
Table 6

Positive Identity $(\mathrm{N}=68)$

\begin{tabular}{|c|c|c|c|c|c|c|c|c|}
\hline & \multicolumn{2}{|c|}{$\begin{array}{l}\text { Strongly } \\
\text { Disagree }\end{array}$} & \multicolumn{2}{|c|}{ Disagree } & \multicolumn{2}{|c|}{ Agree } & \multicolumn{2}{|c|}{$\begin{array}{l}\text { Strongly } \\
\text { Agree }\end{array}$} \\
\hline & $f$ & $\%$ & $f$ & $\%$ & $f$ & $\%$ & $f$ & $\%$ \\
\hline I can do things on my own. & 0 & 0.0 & 6 & 8.8 & 31 & 45.6 & 31 & 45.6 \\
\hline $\begin{array}{l}\text { I am comfortable giving a } \\
\text { speech in front of people. }\end{array}$ & 6 & 9.0 & 20 & 29.9 & 31 & 46.3 & 10 & 14.9 \\
\hline $\begin{array}{l}\text { I have control over the things } \\
\text { that will happen in my life }\end{array}$ & 6 & 9.1 & 15 & 22.7 & 32 & 48.5 & 13 & 19.7 \\
\hline On the whole, I like myself. & 1 & 1.5 & 6 & 8.8 & 27 & 39.7 & 34 & 50.0 \\
\hline All in all, I am glad I am me. & 1 & 1.5 & 5 & 7.5 & 20 & 29.9 & 41 & 61.2 \\
\hline I feel I have much to be proud. & 1 & 1.5 & 8 & 11.8 & 22 & 32.4 & 37 & 54.4 \\
\hline I feel like my life has purpose. & 2 & 3.0 & 2 & 3.0 & 30 & 44.8 & 33 & 49.3 \\
\hline $\begin{array}{l}\text { When things don't go well for } \\
\text { me, I do not give up. }\end{array}$ & 7 & 10.6 & 9 & 13.6 & 33 & 50.0 & 17 & 25.8 \\
\hline $\begin{array}{l}\text { I am responsible for my own } \\
\text { actions. }\end{array}$ & 3 & 4.4 & 2 & 2.9 & 42 & 61.8 & 21 & 30.9 \\
\hline $\begin{array}{l}\text { I am comfortable giving a } \\
\text { demonstration in front of } \\
\text { people. }\end{array}$ & 7 & 10.4 & 15 & 22.4 & 30 & 44.8 & 15 & 22.4 \\
\hline I am a good organizer. & 4 & 6.1 & 16 & 24.2 & 37 & 56.1 & 9 & 13.6 \\
\hline I am a good money manager. & 4 & 6.2 & 18 & 27.7 & 31 & 47.7 & 12 & 18.5 \\
\hline $\begin{array}{l}\text { I have good written record } \\
\text { keeping skills (such as keeping } \\
\text { a journal or diary). }\end{array}$ & 8 & 11.8 & 32 & 47.1 & 17 & 25.0 & 11 & 16.2 \\
\hline
\end{tabular}


Table 7

Asset Development

\begin{tabular}{lcc}
\hline & Mean & SD \\
\hline Positive Identity & 3.04 & .38 \\
Social Competency & 3.07 & .41 \\
Self Confidence & 3.35 & .43 \\
Empowerment & 3.02 & .47 \\
Conversations with Adults & 3.44 & .43 \\
\hline
\end{tabular}

\section{Social Competency}

A composite score of the social competency variables: making friends, caring about other people's feelings, feeling sad when a friend is unhappy, volunteer in class to lead activities, meet new people easily, comfortable in new situations, good at planning ahead, feel other kids look up to them, feel other kids follow their example, are good a keeping friends, set goals, and think they will be happy in 10 years was used to create the mean. The mean for social competency was 3.07, with a standard deviation of .41 (see Table 7).

Thirty-three participants (49.3\%) strongly agreed and 29 (43.3\%) agreed that they are good at making friends. Three (4.5\%) students disagreed and two (3.0\%) strongly disagreed that they were good at making friends. The median was strongly agreed (see Table 8).

Thirty-one (47\%) respondents agreed and 33 students (50\%) strongly agreed and that they care about other people's feelings. One respondent (1.5\%) 
disagreed and one (1.5\%) strongly disagreed with the statement. The median was strongly agreed.

When participants were asked if they feel sad when a friend was unhappy, 37 students (55.2\%) agreed and 24 (35.8\%) strongly agreed. Six students (9\%) disagreed and no respondent strongly disagreed with the statement. The median for feeling sad when a friend was unhappy was agreed.

Thirty-one students (45.6\%) agreed that they volunteer in class to lead activities, while 12 respondents (17.6\%) strongly agreed. Twenty-one students (30.9\%) disagreed and four (5.9\%) strongly disagreed that they volunteer in class to lead activities. The median was agreed.

Thirty-nine participants (57.4\%) agreed they could meet new people easily and $18(26.5 \%)$ strongly agreed. Eight students (11.8\%) disagreed and three (4.4\%) strongly disagreed. The median was agreed for if they could meet new people easily.

When students were asked if they were comfortable in new situations, 31 (47\%) agreed and ten (15.2\%) strongly agreed. Twenty-two (33.3\%) disagreed and three (4.5\%) strongly disagreed. The median was agreed.

Thirty students (46.2\%) agreed they were good at planning ahead, while 13 participants (20\%) strongly agreed. Twenty (30.8\%) disagreed and two (3.1\%) strongly disagreed they were good at planning ahead. The median was agreed.

Thirty-six respondents (55.4\%) agreed that they feel other kids look up to them, while 13 (20\%) strongly agreed. Twenty (30.8\%) disagreed, while three 
(4.6\%) strongly disagreed that they felt others kids look up to them. The median was agreed.

Forty-one students (61.2\%) agreed that other kids follow their example, while seven (10.4\%) strongly agreed. Fifteen respondents (22.4\%) disagreed with the statement, while four (6.0\%) strongly disagreed. The median was agreed.

Thirty-three (50\%) students agreed and $30(45.5 \%)$ strongly agreed that 10 years from now they believe they will be very happy. One (1.5\%) disagreed and two (3.0\%) strongly disagreed. The median was agreed.

Thirty-seven respondents (54.4\%) strongly agreed they are good at keeping friends and 30 (44.1\%) agreed. One (1.5\%) strongly disagreed and no respondent disagreed. The median was strongly agreed.

When participants were asked if they set goals, 35 students (51.5\%) agreed and $22(32.4 \%)$ strongly agreed. Nine (13.2\%) disagreed and two (2.9\%) strongly disagreed. The mode was agreed (see Table 8). 
Table 8

Social Competency ( $N=68)$

\begin{tabular}{|c|c|c|c|c|c|c|c|c|}
\hline & \multicolumn{2}{|c|}{$\begin{array}{l}\text { Strongly } \\
\text { Disagree }\end{array}$} & \multicolumn{2}{|c|}{ Disagree } & \multicolumn{2}{|c|}{ Agree } & \multicolumn{2}{|c|}{$\begin{array}{l}\text { Strongly } \\
\text { Agree }\end{array}$} \\
\hline & $f$ & $\%$ & $f$ & $\%$ & $f$ & $\%$ & $f$ & $\%$ \\
\hline I am good at making friends. & 2 & 3.0 & 3 & 4.5 & 29 & 43.3 & 33 & 49.3 \\
\hline $\begin{array}{l}\text { I care about other people's } \\
\text { feelings. }\end{array}$ & 1 & 1.5 & 1 & 1.5 & 31 & 47.0 & 33 & 50.0 \\
\hline $\begin{array}{l}\text { I feel really sad when one of my } \\
\text { friends is unhappy. }\end{array}$ & 0 & 0.0 & 6 & 9.0 & 37 & 55.2 & 24 & 35.8 \\
\hline $\begin{array}{l}\text { I volunteer in class to lead } \\
\text { activities. }\end{array}$ & 4 & 5.9 & 21 & 30.9 & 31 & 45.6 & 12 & 17.6 \\
\hline I can meet new people easily. & 3 & 4.4 & 8 & 11.8 & 39 & 57.4 & 18 & 26.5 \\
\hline $\begin{array}{l}\text { I am comfortable in new } \\
\text { situations. }\end{array}$ & 3 & 4.5 & 22 & 33.3 & 31 & 47.0 & 10 & 15.2 \\
\hline I am good at planning ahead. & 2 & 3.1 & 20 & 30.8 & 30 & 46.2 & 13 & 20.0 \\
\hline I feel other kids look up to me. & 3 & 4.6 & 13 & 20.0 & 36 & 55.4 & 13 & 20.0 \\
\hline $\begin{array}{l}\text { I feel other kids follow my } \\
\text { example. }\end{array}$ & 4 & 6.0 & 15 & 22.4 & 41 & 61.2 & 7 & 10.4 \\
\hline $\begin{array}{l}\text { Ten years from now, I think I will } \\
\text { be very happy. }\end{array}$ & 2 & 3.0 & 1 & 1.5 & 33 & 50.0 & 30 & 45.5 \\
\hline I am good at keeping friends. & 1 & 1.5 & 0 & 0.0 & 30 & 44.1 & 37 & 54.4 \\
\hline I set goals. & 2 & 2.9 & 9 & 13.2 & 35 & 51.5 & 22 & 32.4 \\
\hline
\end{tabular}




\section{Self Confidence}

A composite score of the self confidence variables: staying away from people who might get them in trouble, knowing how to say no when someone wants them to do things they know are threatening to their well-being, finding a way to work through it when things do not go well, knowing how to say no when someone wants them to do things they know are wrong was used to create the mean. The mean for self confidence was 3.35 , with a standard deviation of .43 (see Table 7).

Thirty-seven participants (55.2\%) agreed that they stay away from people who might get them in trouble, and 23 (34.3\%) strongly agreed. Six (9.0\%) disagreed and one (1.5\%) strongly disagreed. The median was agreed.

If something is threatening their well-being, 39 students (57.4\%) strongly agreed that they know how to say no. Twenty-three respondents (33.8\%) agreed, while four (5.9\%) strongly disagreed, and two (2.9\%) disagreed. The median was strongly agreed.

Forty-two (61.8\%) students agreed they find a way to work through it when things don't go well for them, and 21 (30.9\%) strongly agreed. Three (4.4\%) disagreed and two (2.9\%) strongly disagreed. The median was agreed.

Forty respondents (58.8\%) strongly agreed and 26 (38.2\%) agreed that they know how to say no when someone wants them to do things they know are wrong. Two (2.9\%) disagreed while no respondents strongly disagreed. The median was strongly agreed (see Table 9). 
Table 9

Self Confidence $(N=68)$

\begin{tabular}{|c|c|c|c|c|c|c|c|c|}
\hline & \multicolumn{2}{|c|}{$\begin{array}{l}\text { Strongly } \\
\text { Disagree }\end{array}$} & \multicolumn{2}{|c|}{ Disagree } & \multicolumn{2}{|c|}{ Agree } & \multicolumn{2}{|c|}{$\begin{array}{l}\text { Strongly } \\
\text { Agree }\end{array}$} \\
\hline & $f$ & $\%$ & $f$ & $\%$ & $f$ & $\%$ & $f$ & $\%$ \\
\hline $\begin{array}{l}\text { I stay away from people who } \\
\text { might get me in trouble. }\end{array}$ & 1 & 1.5 & 6 & 9.0 & 37 & 55.2 & 23 & 34.3 \\
\hline $\begin{array}{l}\text { I know how to say "no" when } \\
\text { someone wants me to do things } \\
\text { I know are threatening to my } \\
\text { well-being. }\end{array}$ & 4 & 5.9 & 2 & 2.9 & 23 & 33.8 & 39 & 57.4 \\
\hline $\begin{array}{l}\text { When things don't go well for } \\
\text { me, I find a way to work through } \\
\text { it. }\end{array}$ & 2 & 2.9 & 3 & 4.4 & 42 & 61.8 & 21 & 30.9 \\
\hline $\begin{array}{l}\text { I know how to say "no" when } \\
\text { someone wants me to do things } \\
\text { I know are wrong. }\end{array}$ & 0 & 0.0 & 2 & 2.9 & 26 & 38.2 & 40 & 58.8 \\
\hline
\end{tabular}

\section{Empowerment}

A composite score of the empowerment variables: adults in their community listen to what they have to say, feeling useful in their family, adults in their community make them feel important, adults in their home town care about people their age, they feel like they matter to people in their home town, they feel important in their family, students help decide what goes on at their school, they are given lots of chances to help make their town or community a better place to 
live was used to create the mean. The mean for empowerment was 3.02, with a standard deviation of .47 (see Table 7).

Forty-one respondents (61.2\%) agreed that adults in their community listen to what they have to say, while 10 (14.9\%) students strongly agreed. Twelve (17.9\%) disagreed with the statement, while four (6.0\%) strongly disagreed. Agreed was the median.

Twenty-eight (41.8\%) students agreed and 28 (41.8\%) strongly agreed that they feel useful in their family. Seven respondents (10.4\%) disagreed and four (6.0\%) strongly disagreed. The median was agreed.

When participants were asked if adults in their community make them feel important, 37 (55.2\%) agreed, while 13 (19.4\%) strongly agreed. Fourteen students (20.9\%) disagreed and three (4.5\%) strongly disagreed with the statement. Agreed was the median.

Thirty-seven (55.2\%) respondents agreed that adults in their home town care about people their age and 21 (31.3\%) strongly agreed. Nine (13.4\%) students disagreed and none strongly disagreed. The median was agreed.

Thirty-seven participants (55.2\%) agreed and 16 (23.9\%) strongly agreed that they felt like they mattered to people. Eleven students (16.4\%) disagreed and three (4.5\%) strongly disagreed with the statement. The median was agreed.

Twenty-five respondents (37.3\%) agreed and 39 students (58.2\%) strongly agreed that they feel important in their family. Three (4.5\%) disagreed and no respondents strongly disagreed. Strongly agreed was the median. 
Thirty-four respondents (50.7\%) agreed that students help decide what goes on at their school, while 12 students (17.9\%) strongly agreed. Seventeen (25.4\%) disagreed with the statement, while four (6.0\%) strongly disagreed. Agreed was the median.

Thirty-one students (46.3\%) agreed and 12 (17.9\%) strongly agreed that they are given opportunities to improve their town or community. Seventeen students (25.4\%) disagreed and four (6.0\%) strongly disagreed they are given opportunities to improve their town or community. The median was agreed (see Table 10).

\section{Conversations with Adults}

A composite score of the conversations with adults variables: having a conversation with a parent or guardian within the last month that lasted 10 minutes or more, having a conversation with an adult other than a parent or guardian within the last month that lasted 10 minutes or more, and if there was an adult other than their parent or guardian to whom they would feel comfortable going to for help if they had an important question about their life was used to create the mean. The mean for conversations with adults was 3.44 , with a standard deviation of .43 (see Table7).

When the students were asked if they had an adult to go to for help, 63 (92.6\%) reported they did, while $5(7.4 \%)$ said they did not. Sixty-five students (95.6\%) reported they had a conversation with parent/guardian that lasted longer than 10 minutes in the past month, while three (4.4\%) said they had not. Fifty-six 
students (83.6\%) reported they had a conversation with an adult other than a parent/guardian that lasted longer than 10 minutes in the past month, while 11 (16.4\%) said they had not. The mode for all three was yes (see Table 11).

Table 10

Empowerment $(N=68)$

\begin{tabular}{cccccccc}
$\begin{array}{c}\text { Strongly } \\
\text { Disagree }\end{array}$ & Disagree & Agree & \multicolumn{2}{c}{$\begin{array}{c}\text { Strongly } \\
\text { Agree }\end{array}$} \\
\hline$f \quad \%$ & $f$ & $\%$ & $f$ & $\%$ & $f$ & $\%$ \\
\hline
\end{tabular}

Adults in my community listen to what I have to say.

$\begin{array}{llllllll}4 & 6.0 & 12 & 17.9 & 41 & 61.2 & 10 & 14.9\end{array}$

In my family, I feel useful.

$\begin{array}{llllllll}4 & 6.0 & 7 & 10.4 & 28 & 41.8 & 28 & 41.8\end{array}$

Adults in my community make me feel important.

$\begin{array}{llllllll}3 & 4.5 & 14 & 20.9 & 37 & 55.2 & 13 & 19.4\end{array}$

Adults in my home town care about people my age.

$\begin{array}{llllllll}0 & 0.0 & 9 & 13.4 & 37 & 55.2 & 21 & 31.3\end{array}$

In my home town, I feel like I

matter to people.

$\begin{array}{llllllll}3 & 4.5 & 11 & 16.4 & 37 & 55.2 & 16 & 23.9\end{array}$

In my family, I feel important.

$\begin{array}{llllllll}0 & 0.0 & 3 & 4.5 & 25 & 37.3 & 39 & 58.2\end{array}$

Students help decide what goes

on at my school.

$\begin{array}{llllllll}4 & 6.0 & 17 & 25.4 & 34 & 50.7 & 12 & 17.9\end{array}$

I'm given lots of chances to help make my town or community a better place to live. $\begin{array}{llllllll}4 & 6.0 & 21 & 31.3 & 31 & 46.3 & 11 & 16.4\end{array}$ $\alpha=.78$ 
Table 11

Conversations with Adults $(N=68)$

\begin{tabular}{llllll}
\hline & \multicolumn{2}{c}{ Yes } & \multicolumn{2}{c}{ No } \\
\cline { 2 - 5 } & $f$ & $\%$ & $f$ & $\%$ \\
\hline
\end{tabular}

If you had an important question about your life, is there an adult other than your parents/guardians to whom you would feel comfortable going to for help?

$\begin{array}{llll}63 & 92.6 & 5 & 7.4\end{array}$

In the last month, did you have a conversation with one of your parents/guardians that lasted 10 minutes or more?

$\begin{array}{llll}65 & 95.6 & 3 & 4.4\end{array}$

In the last month, did you have a conversation with an adult other than your parent/guardian that lasted 10 minutes or more?

$\begin{array}{llll}56 & 83.6 & 11 & 16.4\end{array}$

\section{Contact with Parents}

Thirty-three participants (48.5\%) agreed and 29 (42.6\%) strongly agreed that they get along well with their parents. Six (8.8\%) students disagreed with the statement. The median was agreed.

When asked if there were consequences to breaking rules, 35 students (51.5\%) agreed and 30 (44.1\%) strongly agreed. Three students (4.4\%) disagreed with the statement. Agreed was the median.

Forty-one respondents (60.3\%) strongly agreed and 26 (38.2\%) agreed that their parents give help and support when needed. One (1.5\%) student disagreed with the statement. The median was strongly agreed (see Table 12). 
Table 12

Contact with Parents $(\mathrm{N}=68)$

\begin{tabular}{lcccccccccc}
\hline & \multicolumn{2}{c}{$\begin{array}{c}\text { Strongly } \\
\text { Disagree }\end{array}$} & Disagree & Agree & \multicolumn{2}{c}{$\begin{array}{c}\text { Strongly } \\
\text { Agree }\end{array}$} \\
\cline { 2 - 11 } & $f$ & $\%$ & $f$ & $\%$ & $f$ & $\%$ & $f$ & $\%$ \\
\hline I get along well with my parents. & 0 & 0.0 & 6 & 8.8 & 33 & 48.5 & 29 & 42.6 \\
$\begin{array}{l}\text { If I break one of my parents' } \\
\text { rules, there are consequences. }\end{array}$ & 0 & 0.0 & 3 & 4.4 & 35 & 51.5 & 30 & 44.1 \\
$\begin{array}{l}\text { My parents give me help and } \\
\text { support when I need it. }\end{array}$ & 0 & 0.0 & 1 & 1.5 & 26 & 38.2 & 41 & 60.3 \\
\hline
\end{tabular}

\section{Leadership Roles}

In regards to leadership roles in the past year, 52 respondents $(77.6 \%)$ had not held a leadership position in school and 56 (83.6\%) had not held a leadership role out of school. Six (9\%) reported being a committee member in school, while three (4.5\%) had been a committee member out of school. One person (1.5\%) had been a committee chairperson in school, with no respondent reporting being a committee chairperson out of school. No one (0\%) reported being an officer of an organization in school, while one (1.5\%) reported being an officer out of school. Eight (11.9\%) reported other leadership roles in school, such as Math Field Day, Group Time Leader, Student Council, Tudor, and Team Captains (see Appendix I). Seven (10.4\%) reported they held other leadership roles out of school, such as community service, pledge, sports, Energy Express volunteer, Assistant Coach in League Sports, Assistant and Patrol Leader. The median and mode for leadership roles was zero (see Table 13). 
Table 13

Leadership Roles $(N=68)$

\begin{tabular}{lcccc}
\hline & \multicolumn{2}{c}{$\begin{array}{c}\text { Leadership roles held in } \\
\text { school in the past year }\end{array}$} & \multicolumn{2}{c}{$\begin{array}{l}\text { Leadership roles held out } \\
\text { of school in the past year }\end{array}$} \\
\cline { 2 - 5 } & $f$ & $\%$ & $f$ & $\%$ \\
\hline None & 52 & 77.6 & 56 & 83.6 \\
$\begin{array}{l}\text { Officer of an } \\
\text { organization }\end{array}$ & 0 & 0.0 & 1 & 1.5 \\
$\begin{array}{l}\text { Committee member } \\
\begin{array}{l}\text { Committee } \\
\text { chairperson }\end{array}\end{array}$ & 6 & 9.0 & 3 & 4.5 \\
Other & 1 & 1.5 & 0 & 0.0 \\
\hline
\end{tabular}

\section{4-H Membership}

Eight (11.8\%) of the 68 respondents said they had been a 4- $\mathrm{H}$ member (see Table 14). Three (37.5\%) of the eight respondents who had been in 4-H responded that they were currently in $4-\mathrm{H}$ (see Table 15).

Table 14

4-H Membership Ever ( $N=68)$

$$
\text { f } \%
$$

4-H Membership Ever

Yes

8

11.8

No

60

88.2 
Table 15

4-H Membership Current $(N=8)$

\begin{tabular}{lll}
\hline & $f$ & $\%$ \\
\hline 4-H Membership Current & & \\
Yes & 3 & 37.5 \\
No & 5 & 62.5 \\
\hline
\end{tabular}

\section{Years in 4-H}

Of those reporting 4-H membership, three participants (37.5\%) were in 4$\mathrm{H}$ for one year, while two (25\%) were in $4-\mathrm{H}$ for three years. For the duration of 4-H membership categories for two, four, and six years, there was one respondent (12.5\%) in each category. Due to the young age of the respondents, there were not any who had participated in 4- $\mathrm{H}$ for seven years or more. (see Table 16).

\section{4-H Club Type}

Of those reporting 4-H memberships, five youth reported participating in a 4-H Community Club (62.5\%), while four youth reported participating in an Afterschool Club (50\%). One youth reported being involved with both a community club and an afterschool club (see Table 17). 
Table 16

Years in $4-H(N=8)$

\begin{tabular}{lll}
\hline & $f$ & $\%$ \\
\hline 1 & 3 & 37.5 \\
2 & 1 & 12.5 \\
3 & 2 & 25.0 \\
4 & 1 & 12.5 \\
5 & 0 & 0.0 \\
6 & 1 & 12.5 \\
7 & 0 & 0.0 \\
8 & 0 & 0.0 \\
9 & 0 & 0.0 \\
10 or more years & 0 & 0.0 \\
\hline
\end{tabular}

Table 17

4-H Club Type $(\mathrm{N}=8)$

\begin{tabular}{lrrrr}
\hline & \multicolumn{2}{c}{ Yes } & \multicolumn{2}{c}{ No } \\
\cline { 2 - 5 } & $f$ & $\%$ & $f$ & $\%$ \\
\hline 4-H Community Club & 5 & 62.5 & 3 & 37.5 \\
4-H In-School Club & 0 & 0.0 & 8 & 100.0 \\
4-H Afterschool Club & 4 & 50.0 & 4 & 50.0 \\
4-H Military Club & 0 & 0.0 & 8 & 100.0 \\
4-H Special Interest Group & 0 & 0.0 & 8 & 100.0 \\
4-H Member at large & 0 & 0.0 & 8 & 100.0 \\
Other: & 0 & 0.0 & 8 & 100.0 \\
\hline
\end{tabular}




\section{4-H Activities}

Of the respondents reporting 4-H membership, six 4-Her's (75\%) responded that they had been involved with $4-\mathrm{H}$ projects/fair exhibits and four (50\%) participated in 4-H Camp, two (25\%) youth reported they participated in 4H Officer's Training and two (25\%) in 4-H public speaking/presentations. One respondent each (12.5\%) said they participated in 4-H judging events and skillathons. One respondent (12.5\%) reported other and wrote in hiking, art, fishing, and dance (see Table 18 \& Appendix I).

Table 18

4-H Activity Type $(\mathrm{N}=8)$

\begin{tabular}{lcccc}
\hline & \multicolumn{2}{c}{ Yes } & \multicolumn{2}{c}{ No } \\
\cline { 2 - 5 } & $f$ & $\%$ & $f$ & $\%$ \\
\hline 4-H Camp & 4 & 50.0 & 4 & 50.0 \\
4-H Officers' Training & 2 & 25.0 & 6 & 75.0 \\
4-H projects/fair exhibits & 6 & 75.0 & 2 & 25.0 \\
4-H public & & & & \\
speaking/presentations & 2 & 25.0 & 6 & 75.0 \\
4-H judging events & 1 & 12.5 & 7 & 87.5 \\
4-H Skillathons & 1 & 12.5 & 7 & 87.5 \\
Other: & 1 & 12.5 & 7 & 87.5 \\
\hline
\end{tabular}




\section{4-H Participation}

Of the respondents reporting 4- $\mathrm{H}$ membership, the median for all the 4- $\mathrm{H}$ participation was agree. When asked if $4-\mathrm{H}$ participation helped them be successful, four students (57.1\%) agreed and three (42.9\%) strongly agreed (see Table 19).

Three (42.9\%) 4-H member respondents agreed and three (42.9\%) strongly agreed that 4-H made a positive difference in their life. One (14.3\%) student disagreed and no respondents who reported 4-H membership strongly disagreed.

Three 4-H member participants (50\%) agreed that 4- $\mathrm{H}$ made a positive difference in their family's life. Two students (33.3\%) disagreed, one (16.7\%) strongly agreed, and no respondents who reported 4- $\mathrm{H}$ membership strongly disagreed.

Six 4- $\mathrm{H}$ member respondents (85.7\%) agreed that if it were not for $4-\mathrm{H}$, there would be other organized activities of interest outside of school time in the community. One student (14.3\%) disagreed and no respondents who reported 4$\mathrm{H}$ membership strongly agreed or strongly disagreed.

Five 4-H member respondents (71.4\%) agreed and two (28.6\%) strongly agreed that $4-\mathrm{H}$ provides a safe place for learning new materials. No respondents who reported 4-H membership responded that they disagreed or strongly disagreed. 
Five 4-H member respondents (71.4\%) agreed and two (28.6\%) strongly agreed that 4-H provides a safe place to be involved. No respondents who reported 4-H membership reported that they disagreed or strongly disagreed.

Six 4-H member participants (85.7\%) agreed and one (14.3\%) strongly agreed that 4-H clubs are a place where they can feel accepted for who they really are. No respondents who reported $4-\mathrm{H}$ membership reported that they disagreed or strongly disagreed with the statement.

Six 4-H member participants (85.7\%) agreed and one (14.3\%) strongly agreed that they can explore their own interest areas in $4-\mathrm{H}$. None of the respondents who reported 4-H membership disagreed or strongly disagreed with the statement.

Five 4-H member students (71.4\%) agreed and one (14.3\%) strongly agreed that $4-\mathrm{H}$ leaders made a positive difference their life. One (14.3\%) participant disagreed and none of the respondents who reported 4-H membership strongly disagreed.

Four (57.1\%) 4-H member respondents agreed they could ask 4-H leaders any question they have. One student (14.3\%) strongly agreed, one (14.3\%) disagreed, and one (14.3\%) strongly disagreed they could ask 4-H leaders any questions they had.

Three 4-H member participants (42.9\%) agreed and two (28.6\%) strongly agreed that 4-H helped them develop leadership skills. Two students (28.3\%) disagreed, while no one strongly disagreed. 
Table 19

4-H Participation $(\mathrm{N}=8)$

\begin{tabular}{ccccccccc}
\hline $\begin{array}{c}\text { Strongly } \\
\text { Disagree }\end{array}$ & Disagree & Agree & $\begin{array}{c}\text { Strongly } \\
\text { Agree }\end{array}$ \\
\hline$f$ & $\%$ & $f$ & $\%$ & $f$ & $\%$ & $f$ & $\%$ \\
\hline
\end{tabular}

Participation in 4-H has helped me be successful.

$\begin{array}{llllllll}0 & 0.0 & 0 & 0.0 & 4 & 57.1 & 3 & 42.9\end{array}$

4-H has made a positive

difference in my life.

$\begin{array}{llllllll}0 & 0.0 & 1 & 14.3 & 3 & 42.9 & 3 & 42.9\end{array}$

4-H has made a positive

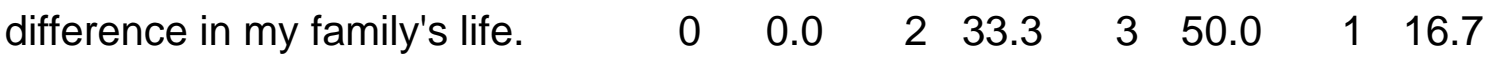

If it weren't for $4-\mathrm{H}$, there would be other organized activities of interest to me outside of school time in my community.

$\begin{array}{llllllll}0 & 0.0 & 1 & 14.3 & 6 & 85.7 & 0 & 0.0\end{array}$

4-H provides a safe place for learning new materials.

$\begin{array}{llllllll}0 & 0.0 & 0 & 0.0 & 5 & 71.4 & 2 & 28.6\end{array}$

4-H provides a safe place for me to be involved.

$\begin{array}{llllllll}0 & 0.0 & 0 & 0.0 & 5 & 71.4 & 2 & 28.6\end{array}$

4-H clubs are a place where I feel accepted for who I am.

$\begin{array}{llllllll}0 & 0.0 & 0 & 0.0 & 6 & 85.7 & 1 & 14.3\end{array}$

In 4- $\mathrm{H}$, I can explore my own interests.

$\begin{array}{llllllll}0 & 0.0 & 0 & 0.0 & 6 & 85.7 & 1 & 14.3\end{array}$

4-H leaders made a positive difference in my life.

$\begin{array}{llllllll}0 & 0.0 & 1 & 14.3 & 5 & 71.4 & 1 & 14.3\end{array}$

I feel I could ask 4-H leaders $\begin{array}{llllllllll}\text { any question I might have. } & 1 & 14.3 & 1 & 14.3 & 4 & 57.1 & 1 & 14.3\end{array}$ 
Four 4-H member students (57.5\%) agreed they had taken on leadership roles through $4-\mathrm{H}$, and one (14.3\%) strongly agreed. One participant (14.3\%) disagreed and one (14.3\%) strongly disagreed (see Table 19).

Table 20

4- $H$ Participation $(N=8)$ (continued)

\begin{tabular}{|c|c|c|c|c|c|c|c|c|}
\hline & \multicolumn{2}{|c|}{$\begin{array}{l}\text { Strongly } \\
\text { Disagree }\end{array}$} & \multicolumn{2}{|c|}{ Disagree } & \multicolumn{2}{|c|}{ Agree } & \multicolumn{2}{|c|}{$\begin{array}{l}\text { Strongly } \\
\text { Agree }\end{array}$} \\
\hline & $f$ & $\%$ & $f$ & $\%$ & $f$ & $\%$ & $f$ & $\%$ \\
\hline $\begin{array}{l}\text { I feel } 4-\mathrm{H} \text { has helped me } \\
\text { develop leadership skills. }\end{array}$ & 0 & 0.0 & 2 & 28.6 & 3 & 42.9 & 2 & 28.6 \\
\hline $\begin{array}{l}\text { I have taken on leadership roles } \\
\text { through } 4-\mathrm{H} \text {. }\end{array}$ & 1 & 14.3 & 1 & 14.3 & 4 & 57.1 & 1 & 14.3 \\
\hline
\end{tabular}

\section{Use of Findings}

Information gained from the study could be used by youth development professionals, funders, and policy makers to make more informed decisions. Since so many of the youth were not involved in clubs or organizations either in or out of school, youth development professionals could look at ways to increase access to programs and activities. 


\section{CHAPTER V}

\section{Summary, Conclusions, and Recommendations}

\section{Purpose of Study}

Research is needed to quantitatively demonstrate to stakeholders the effects of Out of School Time activities in West Virginia. Being able to demonstrate the impact of Out of School Time activities will enhance efforts to improve the programs and to secure additional funding sources.

The purpose of the study is to describe what Out of School Time activities youth participated in in rural West Virginia and to see if these activities correlate to increased life skills in youth. The study will also provide information needed to suggest areas for program improvement.

\section{Objectives of the Study}

The objectives are reflected in the following research questions:

1. How do youth in West Virginia spend Out of School Time?

2. Do Out of School Time programs increase positive assets in youth?

3. Does the number of hours participating in Out of School Time activities affect the amount of developmental assets received?

4. Is there a correlation between assets received and the students' self-reported academic performance?

5. Is there a correlation between assets received and the students' leadership positions held? 
6. Is there a correlation between assets received and the students' having a positive self-identity?

7. Is there a correlation between assets received and the students' level of empowerment?

8. Is there a correlation between assets received and the students' conversations with adults?

9. Is there a correlation between assets received and the students' contact with parents?

10. Is there a correlation between assets received and the students' self-confidence?

11. Is there a correlation between assets received and the students' contributions to others and the community?

\section{Summary}

In structured activities, a majority of the respondents reported they spent time in arts and music, playing or assisting with sports, and attending religious services. Over $75 \%$ spent one hour or more with music and arts activities each week. A majority of the respondents did not spend time in clubs or organizations either in school $(75 \%)$ or out of school (86\%).

In regards to unstructured activities, a majority of the respondents reported being physically active, $97 \%$ spending 1 or more hours per week.

Four to nine hours a week were spent hanging out with friends by $50 \%$ of the respondents. Students (73\%) watched one to six hours of television per 
week. Only $35 \%$ reported participating in playing video games one to three hours per week, while $38 \%$ did not play video games at all.

Community service hours reported were extremely low, with a majority of the respondents (61\%) reporting no community service hours in the past year. Less than a third (29\%) of the respondents reported doing one to 10 hours of community service in the past year, except when helping those unable to help themselves, which was just slightly more than a third (35\%).

Respondents had a very strong positive identity with a majority reporting that they could do things on their own (91\%), they felt their lives had purpose (94\%), they liked themselves (90\%) and they were glad to be themselves (91\%). The majority of students reported being good organizers (70\%), good money managers (66\%), and they were comfortable giving speeches (61\%) and demonstrations (67\%). Students reported feeling responsible for their own actions (93\%), they felt control over things that had happened in their lives (68\%), they had much to be proud of, and they did not give up when things did not go well. The only area a majority reported negatively was that they did not feel they had good record keeping skills (41\%).

In social competency, a majority of the respondents reported they meet new people easily (84\%), were good at making friends (93\%), they care about other people's feelings (97\%), they feel sad when a friend is unhappy (91\%), and that other kids look up to them (75\%) and follow their example (72\%). They felt comfortable in new situations (62\%), volunteer in class to lead activities (63\%), 
are good at planning ahead (66\%) and setting goals (84\%). Most respondents (96\%) felt they will be happy ten years from now.

A majority of the respondents were very strong in reporting self confidence. Students reported they could stay away from people who might get them in trouble (90\%) and knew how to say no when someone wanted them to do things they knew were threatening to their well-being (91\%) or that they knew to be wrong. Respondents (92\%) also reported they could find a way to work through it when things didn't go well for them. Ninety-seven percent said they knew how to say no when someone wants them to do things they know are wrong.

Participants were also strong in reporting empowerment, with the highest reporting in feeling important (96\%) and useful in their family (84\%). A majority of the respondents $(76 \%)$ agreed that adults in their community listen to what they have to say, adults in their community make them feel important (75\%), and that adults in their home town care about people their age (87\%). Respondents agreed that they felt like they mattered to people in the community $(79 \%)$ and they were given opportunities to improve their town or community (63\%). Students also agreed that they helped decide what went on at their school (69\%). A majority of the respondents reported having conversations with adults, although the response rate for having conversations with adults other than parent/guardian's (84\%) were lower than those with parents (96\%). The majority of respondents reported getting along well with parents (91\%), receiving help and 
support when needed (99\%), and consequences when breaking parents' rules (96\%).

Leadership roles in the community reported by the respondents were extremely low. The majority did not have any experience in leadership roles either in school $(77 \%)$ or out of school (84\%). There were too few of respondents whom reported having been a 4-H member to make any generalizations.

\section{Conclusions}

Tyler County youth are involved in arts, music, sports, and religious activities. Many do not play video games and the majorities do not participate in any community service.

When comparing Tyler County respondents with regard to characteristics of positive identity, empowerment, and social competency to studies from Colorado, Utah, Idaho, New Mexico, and Ohio, Tyler County youth rated the items much higher than any of the other states on all of the variables. More than twice the number of youth from Tyler County reported that their lives have purpose, compared numbers reported by the other states. Tyler County youth responded at double the rate of other states, that they have much to be proud of.

When the study in West Virginia was compared with studies conducted in Ohio, Colorado, and Idaho, respondents from Tyler County rated items 5-20\% higher in all areas of social competency. Tyler County youth rated themselves significantly higher in volunteering in class to lead activities, meeting people easily, feeling other kids look up to them, and feel other youth follow their 
example. In self-confidence, about $10 \%$ more of the Tyler County respondents reported they would stay away from people who might get them into trouble and knowing how to say no when someone wants them to do something that threatens their well-being than reported in the studies from Ohio, Colorado, or Idaho.

Tyler County youth were more likely than Colorado, Utah, Idaho, New Mexico, and Ohio responded higher in all the variables asked about empowerment. More than $20 \%$ higher responses were reported in regards to adults in their community listen to what they say, make them feel important, care about people their age, and the students feel like they matter to people. Tyler County youth felt more comfortable going to an adult for help with an important question in their lives, and had more conversations with adults and parents that lasted longer than 10 minutes than youth in the Colorado, Idaho, or Ohio studies.

\section{Recommendations}

Based on the findings of this study, the researcher recommends that additional research be conducted statewide and or nationally to determine the current impact of out of school programs for youth. Future studies could also include older youth, such as $11^{\text {th }}$ or $12^{\text {th }}$ graders, where more cumulative impact could be shown, especially in leadership. Quality of the Out of School Time programs should also be compared.

Because so few students in Tyler County participate in clubs or organizations either in or out of school, increasing accessibility to programs 
through rural transportation and/or convenient locations is recommended to increase participation. Stronger quality programs, making more programs available, and recruiting and training quality volunteers could also provide more opportunities and increase participation. A study of what types of activities and programs Tyler County youth would participate in should be conducted to determine interest and barriers to participation. 


\section{REFERENCES}

America After 3PM. (2009). West Virginia After 3PM. Retrieved from: http://www.afterschoolalliance.org/documents/AA3PM_2009/AA3_Factshe et_WV_2009.pdf

Astroth, K. A., \& Haynes, G. W. (2001). Final report of the Montana public school students' out-of-school time study. Bozeman, MT: Montana State University.

Astroth, K. A., \& Haynes, G. W. (2002). More than cows \& cooking: Newest research shows the impact of $4-\mathrm{H}$. Journal of Extension [On-line], 40(4). Retrieved from: http://www.joe.org/joe/2002august/a6.shtml

Benson, P. L. (1990). The troubled journey: A portrait of 6th-12th grade youth. Minneapolis, MN: Search Institute.

Benson, P. L. (1997). All kids are our kids: What communities must do to raise caring and responsible children and adolescents. San Francisco, CA: Jossey-Bass.

Children's Defense Fund 2011 WV (2011). Children in West Virginia. Retrieved from: www.childrensdefense.org/cits

Damon, W. (2004). What is positive youth development? Annals of the American Academy of Political and Social Science, 591, 13-24.

Dillman, D., Smyth, J. D., Christian, L. M. (2009). Internet, Mail, and Mixed-Mode Surveys: The Tailored Design Method. New Jersey: John Wiley \& Sons, Inc.

Dubas, J. S., \& Snider B. A. (1993). The role of community-based youth groups in enhancing learning and achievement through nonformal education. In R. M. Lerner (Ed.), Early adolescence: Perspectives on research, policy, and intervention. Hillsdale, NJ: Lawrence Erlbaum Associates.

Eberhart, S.E. (2009). Determining the Trends of the Impact of 4-H Participation on Youth in the Western Region. Unpublished thesis. Las Cruces, New Mexico.

Goodwin, J., Barnett, C., Pike, M., Peutz, J., Lanting, R., \& Ward, A. (2005, August) Idaho 4-H Impact Study. Journal of Extension [On-line], 43(4). Retrieved from: http://www.joe.org/joe/2005august/a4p.shtml 
Goodwin, J., Carroll, J.B., \& Oliver, M. (2007, August) Accentuating the Positive: Colorado 4-H Impact Study. Journal of Extension [On-line], 45(5). Retrieved from: http://www.joe.org/joe/2007october/rb8p.shtml

Hange, J. (2009). Status of Afterschool Programs in West Virginia. West Virginia Statewide Afterschool Network. Retrieved from: http://wvsan.ext.wvu.edu/r/download/40572

Harvard Family Research Project (2011, March) Out-Of-School Time Programs in Rural Areas. Research Update: Highlights from the Out-Of-School Time Datatbase [On-line] 6. Retrieved from: http://www.hfrp.org/publications-resources/publications-series/researchupdates-highlights-from-the-out-of-school-time-database/research-update6-out-of-school-time-programs-in-rural-areas

Howard, J.W. (2001). Impact assessment of the Texas 4-H and youth development program. (Doctoral Dissertation. TexasA\&M University, 2001). UMI No. 3011729.

Jones, K. R., Ashurst, K. L., Kurzynske, J. (2007, December) County Extension Agents' Perceptions of Positive Developmental Assets for Vulnerable Youth. Journal of Extension [On-line], 45(6). Retrieved from: http://www.joe.org/joe/2007december/rb4.php

Kids Count Databook (2011). West Virginia. The Annie E. Casey Foundation. Retrieved from: http://datacenter.kidscount.org/Databook/2011/OnlineBooks/ForMedia/Sta teProfiles/KCDB2011_profiles_WV_FINAL-rev.pdf

Lee, C. D., Beard, R., \& Straquadine, G. S. (2003). Description of Utah 4-H club members' perceived level of critical elements in the 4-H experience. Paper presented at Western Region Teaching Symposium. Logan, UT: Utah State University.

Leffert, N. \& Herring, R. H. (1998). Shema: Listening to Jewish Youth. Adolescent Task Force Youth Survey Report. Prepared for the Commission on Identity and Continuity, Minneapolis Jewish Federation. (C) The Search Institute.

Lerner, R. M., Fisher, C. B., \& Weinberg, R. A. (2000). Toward a science for the people: Promoting civil society through the application of developmental science. Child Development, 71, 11-20. 
Lewis, D.K. (2008). Ohio public school students' out-of-school time study: Measuring the impact of Ohio's 4-H Youth Development community club program. Unpublished doctoral dissertation, The Ohio State University, Columbus.

Loosli, S. (2002). Making an Impact on Out-of-School Time. Washington, D.C.: Corporation for National Service.

Lyons, S. \& Walsh, N. (2010). Money Well Spent: How positive social investments will reduce incarceration rates, improve public safety, and promote the well-being of communities. A Justice Policy Institute Report. Retrieved from: http://www.justicepolicy.org/images/upload/1009_REP_MoneyWellSpent_PS-DC-AC-JJ.pdf

Perkins, D. F., Borden, L. M., \& Villarruel, F. A. (2001).Community youth development: A plan for action. , 39-56.

Pittman, K.J., \& Wright, M. (1991). Bridging the gap: A rationale for enhancing the role of community organizations promoting youth development. Washington, D.C.: Center for Youth Development and Policy Research.

Robinson, J. P., Shaver, P. R., \& Wrightsman, L. S. (1991). Criteria for scale selection and evaluation. In J. P. Robinson, P. R. Shaver, \& L. S. Wrightsman (Eds.). Measures of personality and social psychological attitudes (pp. 1-16) New York: Academic Press.

Scales, P.C., Benson, P.L., Leffert, N., \& Blyth, D.A. (2000, January) Contribution of Developmental Assets to the Prediction of Adolescents. Applied Developmental Science [On-line], 4(1). Retrieved from: http://www.informaworld.com/smpp/content $\sim \mathrm{db}=\mathrm{all} \sim$ content=a783720659

Scales, P.C. \& Leffert, N. (1999). Developmental Assets. Minneapolis, MN: Search Institute.

Schlink, K. S. (2000, August). Addressing Education Needs of Youth in Today's Society. Journal of Extension [On-line], 38(4). Retrieved from: http://www.joe.org/joe/2000august/comm1.php

Search Institute (2003). Search Institute Profiles of Student Life: Attitudes and Behaviors. Retrieved from: http://www.searchinstitute.org/research/assets/assetfreq

Seevers B.S., Hodnett, F., Van Leeuen, D. (2011, August). Findings of 4-H Impact Studies in Six Western States. Journal of Extension [On-line], 49(4). Retrieved from: http://www.joe.org/joe/2011august/a4.php 
Singletary, L. \& Smith, M. (2004). Nevada 4-H Statewide Impact Assessment. EB-04-01 Reno, Nevada.

Vandell, D. L., Shernoff, D. J., Pierce, K. M., Bolt, D. M., Dadisman, K., \& Brown, B. B. (2005). Activities, engagement, and emotion in after-school programs (and elsewhere). New Directions for Youth Development, 105, 121-129. 
APPENDICES 
APPENDIX A

Permission Letter from School Superintendent 


\section{Tyler County Schools}

P.O. Box 25

Middlebourne, WV 26149

(304) $758-2145$

Fax (304) $758-4566$
Robin L. Daquilante, Superintendent

Linda L. Hoover, President

Kenneth R. Hunt, Vice-President

Dr. Ralph H. Boone, Member

Larry L. Thomas, Member

Jimmy Wyatt, Member

January 17, 2012

Dear Veronica,

I have spoken to all of our principals in regards to your survey, "Out of School Time". All of our principals and I support this endeavor and commend you for your leadership in this task. Our principals will work with you to make this as easy as possible. Feel free to contact the principals at your earliest convenience or you may meet with them if that would work better for you. If you want me to set up a meeting, let me know and I will gladly do that. Good Luck and thank you for your commitment to the students of Tyler County.

Sincerely,

Robin L. Daquilante 
APPENDIX B

Survey Instrument 


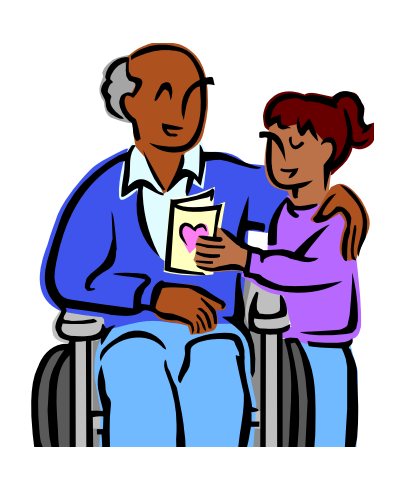

Survey of WV

5 th, 7 th, 9 th

grade out-of-

school time

activities

\section{West Virginia}
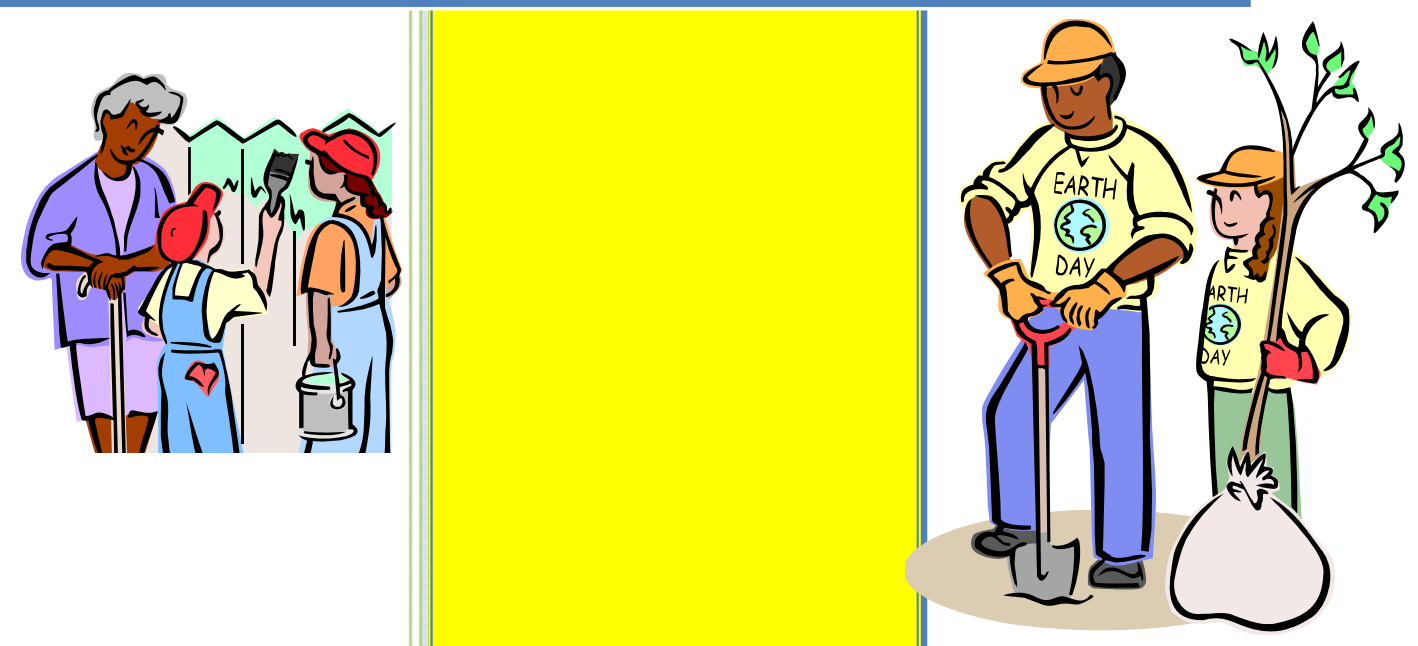

Thank you for completing this questionnaire!

If you have any questions, please contact:

Veronica Wilcox

Graduate Student

veronica.wilcox@mail.wvu.edu

(304) 329-1391

Deborah A. Boone, Ph.D.

Phone: (304) 293-5450

Fax: (304) 293-3752

Email: debby.boone@mail.wvu.edu

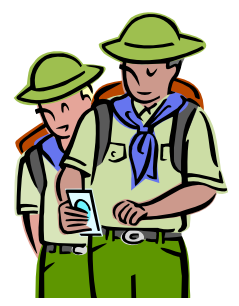




\section{West Virginia Students' OUT-OF-SCHOOL TIME SURVEY}

This is not a test. There is no right or wrong answer. Your participation in this survey is strictly voluntary. Your answers will be kept private. You may stop at any time and do not have to answer every question. Your name will not show anywhere on the survey and you will not be identified with your answers.

Thank you for taking the time to complete this survey!

During a typical week, how many hours do you spend time... circle one answer per statement

\begin{tabular}{|l|l|l|l|l|l|l|l|}
\hline 1. & $\begin{array}{l}\text { in music and the arts, such as drama, art, } \\
\text { dance, band, choir, orchestra, music lessons, } \\
\text { practicing voice or an instrument? }\end{array}$ & None & $1-3$ & $4-6$ & $7-9$ & $10-13$ & $14+$ \\
\hline 2. & $\begin{array}{l}\text { playing on or helping with sports teams at school } \\
\text { or in the community? }\end{array}$ & None & $1-3$ & $4-6$ & $7-9$ & $10-13$ & $14+$ \\
\hline 3. & $\begin{array}{l}\text { in other school clubs or organizations, for } \\
\text { example, school newspaper, student } \\
\text { government, hobby clubs, debate, etc.? }\end{array}$ & None & $1-3$ & $4-6$ & $7-9$ & $10-13$ & $14+$ \\
\hline 4. in 4-H club activities or projects? & None & $1-3$ & $4-6$ & $7-9$ & $10-13$ & $14+$ \\
\hline 5. & $\begin{array}{l}\text { in clubs or organizations (other than sports) } \\
\text { outside of school (such as Scouts, Boys/Girls } \\
\text { Clubs, YWCA, YMCA, etc.)? }\end{array}$ & None & $1-3$ & $4-6$ & $7-9$ & $10-13$ & $14+$ \\
\hline 6. & attending religious services? & None & $1-3$ & $4-6$ & $7-9$ & $10-13$ & $14+$ \\
\hline 7. & hanging out with your friends? & None & $1-3$ & $4-6$ & $7-9$ & $10-13$ & $14+$ \\
\hline 8. & being physically active? & None & $1-3$ & $4-6$ & $7-9$ & $10-13$ & $14+$ \\
\hline 9. & watching television? & None & $1-3$ & $4-6$ & $7-9$ & $10-13$ & $14+$ \\
\hline 10. & playing video games? & None & $1-3$ & $4-6$ & $7-9$ & $10-13$ & $14+$ \\
\hline
\end{tabular}

During the last 12 months, how many hours have you... $\quad$ (circle one answer per statement)

\begin{tabular}{|l|l|l|l|l|l|l|l|l|}
\hline 11. & $\begin{array}{l}\text { been involved in a service activity to } \\
\text { help make life better for other } \\
\text { individuals? Such as writing letters to } \\
\text { service men and women. }\end{array}$ & None & $1-10$ & $11-20$ & $21-30$ & $31-40$ & $41-50$ & $51+$ \\
\hline 12. & $\begin{array}{l}\text { been involved in a service activity to } \\
\text { help make life better for your } \\
\text { community? Such as a trash cleanup. }\end{array}$ & None & $1-10$ & $11-20$ & $21-30$ & $31-40$ & $41-50$ & $51+$ \\
\hline 13. $\begin{array}{l}\text { been involved in a project to help make } \\
\text { life better for the poor, hungry, sick, or } \\
\text { people unable to care for themselves. }\end{array}$ & None & $1-10$ & $11-20$ & $21-30$ & $31-40$ & $41-50$ & $51+$ \\
\hline
\end{tabular}


(Circle one answer per statement)

14. If you had an important question about your life, is there an adult other than your parents/guardians to whom you would feel comfortable going to for help?

15. In the last month, did you have a conversation with one of your parents/ guardians that lasted 10 minutes or more?

16. In the last month, did you have a conversation with an adult other than your parent/guardian that lasted 10 minutes or more?

Please indicate your level of agreement with each of the following statements using $\mathrm{SD}=$ strongly disagree, $\mathrm{D}=$ disagree, $\mathrm{A}=$ agree, and $\mathrm{SA}=$ Strongly agree .

(circle one answer per statement)

\begin{tabular}{|c|c|c|c|c|c|}
\hline & & 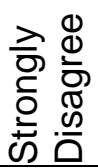 & 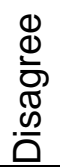 & 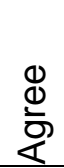 & 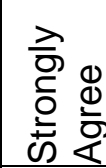 \\
\hline 17. & I can do things on my own. & SD & $\mathrm{D}$ & A & SA \\
\hline 18. & I am comfortable giving a speech in front of people. & SD & $\mathrm{D}$ & A & SA \\
\hline 19. & $\begin{array}{l}\text { I have very little control over the things that will happen } \\
\text { in my life. }\end{array}$ & SD & $\mathrm{D}$ & A & SA \\
\hline 20. & On the whole, I like myself. & SD & $\mathrm{D}$ & A & SA \\
\hline 21. & All in all, I am glad I am me. & SD & $\mathrm{D}$ & A & SA \\
\hline 22. & Adults in my community listen to what I have to say. & SD & $\mathrm{D}$ & A & SA \\
\hline 23. & I feel I have much to be proud of. & SD & $\mathrm{D}$ & A & SA \\
\hline 24. & I feel like my life has purpose. & SD & $\mathrm{D}$ & A & SA \\
\hline 25. & I am good at making friends. & SD & $\mathrm{D}$ & A & SA \\
\hline 26. & I care about other people's feelings. & SD & $\mathrm{D}$ & A & SA \\
\hline 27. & I feel really sad when one of my friends is unhappy. & SD & $\mathrm{D}$ & A & SA \\
\hline 28. & In my family, I feel useful. & SD & $\mathrm{D}$ & A & SA \\
\hline 29. & I stay away from people who might get me in trouble. & SD & $\mathrm{D}$ & A & SA \\
\hline 30. & I volunteer in class to lead activities. & SD & $\mathrm{D}$ & A & SA \\
\hline 31. & I can meet new people easily. & SD & $\mathrm{D}$ & A & SA \\
\hline 32. & I am comfortable in new situations. & SD & $\mathrm{D}$ & A & SA \\
\hline 33. & I am good at planning ahead. & SD & $\mathrm{D}$ & A & SA \\
\hline 34. & I feel other kids look up to me. & SD & $\mathrm{D}$ & A & SA \\
\hline 35. & I feel other kids follow my example. & SD & $\mathrm{D}$ & A & SA \\
\hline 36. & When things don't go well for me, I give up. & SD & $\mathrm{D}$ & A & SA \\
\hline 37. & Ten years from now, I think I will be very happy. & SD & $\mathrm{D}$ & A & SA \\
\hline 38. & $\begin{array}{l}\text { I know how to say "no" when someone wants me to do } \\
\text { things I know are threatening to my well-being. }\end{array}$ & SD & $\mathrm{D}$ & A & SA \\
\hline 39. & I am responsible for my actions. & SD & $\mathrm{D}$ & A & SA \\
\hline 40. & Adults in my community make me feel important. & SD & $\mathrm{D}$ & A & SA \\
\hline 41. & $\begin{array}{l}\text { When things don't go well for me, I find a way to work } \\
\text { through it. }\end{array}$ & SD & $\mathrm{D}$ & A & SA \\
\hline 42. & Adults in my home town care about people my age. & SD & $\mathrm{D}$ & A & SA \\
\hline 43. & In my home town, I feel like I matter to people. & SD & $\mathrm{D}$ & A & SA \\
\hline 44. & I am good at keeping friends. & SD & $\mathrm{D}$ & A & SA \\
\hline 45. & In my family, I feel important. & SD & $\mathrm{D}$ & A & SA \\
\hline 46. & Students help decide what goes on at my school. & SD & $\mathrm{D}$ & A & SA \\
\hline
\end{tabular}




\begin{tabular}{|c|c|c|c|c|c|}
\hline & & 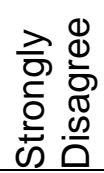 & 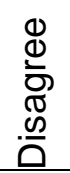 & $\begin{array}{l}\frac{\Phi}{2} \\
\frac{\pi}{2}\end{array}$ & 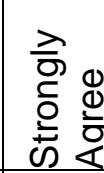 \\
\hline 47. & I set goals. & $\mathrm{SD}$ & $\bar{D}$ & A & SA \\
\hline 48. & $\begin{array}{l}\text { I am comfortable giving a demonstration in front of } \\
\text { people. }\end{array}$ & SD & D & A & SA \\
\hline 49. & I am a good organizer. & SD & $\mathrm{D}$ & A & SA \\
\hline 50. & I am a good money manager. & SD & $\mathrm{D}$ & A & SA \\
\hline 51. & I get along well with my parents. & SD & $\mathrm{D}$ & A & SA \\
\hline 52. & $\begin{array}{l}\text { If I break one of my parents' rules, there are } \\
\text { consequences. }\end{array}$ & SD & D & A & SA \\
\hline 53. & My parents give me help and support when I need it. & SD & $\mathrm{D}$ & A & SA \\
\hline 54. & $\begin{array}{l}\text { I know how to say "no" when someone wants me to do } \\
\text { things I know are wrong. }\end{array}$ & SD & D & A & SA \\
\hline 55. & $\begin{array}{l}\text { I have good written record keeping skills (such as } \\
\text { keeping a journal or diary) }\end{array}$ & SD & $\mathrm{D}$ & A & SA \\
\hline 56. & $\begin{array}{l}\text { I'm given lots of chances to help make my town or } \\
\text { community a better place to live. }\end{array}$ & SD & D & A & \\
\hline
\end{tabular}

57. Which of the following leadership roles have you held in school in the past year?

O None

$\bigcirc$ Officer of an organization

○ Committee member

0 Committee chairperson

O Other, please list:

58. Which of the following leadership roles have you held out of school in the past year?

O None

O Officer of an organization

- Committee member

O Committee chairperson

O Other, please list:

59. What grade are you in?

$$
\begin{array}{ll}
0 & 5^{\text {th }} \text { grade } \\
\circ & 7^{\text {th }} \text { grade } \\
\circ & 9^{\text {th }} \text { grade }
\end{array}
$$

60 . What age range are you in?
O 8- 9 years old
o 10-11 years old
O 12-13 years old
O 14-15 years old
O 16-17 years old
O 18+ years old

61. Are you male or female?

○ Male

○ Female 
62. Where does your family live now?

O On a farm

O In the country, not on a farm

o In town

63. What kind of grades do you earn in school?

O Mostly A's

O A's and B's

O Mostly B's

O B's and C's

O Mostly C's

O C's and D's

O Mostly D's

O Mostly below D's

64. Have you ever been a 4- $\mathrm{H}$ member? (circle one answer)

$\bigcirc$ Yes - If yes, continue with the next question.

○ No - If no, thank you for completing the survey!

65. How many years have you been a $4-\mathrm{H}$ member?
○ 1
○ 2
○ 3
○ 4
○ 5
○ 6
○ 7
○ 8
○ 9
- 10 or more

66. Are you currently a 4-H member?
O Yes
O No

67. What type of 4-H club do you or have you belonged? Check all that apply.

O 4-H Community Club

O 4-H In-School Club

O 4-H Afterschool Club

O 4-H Military Club

O 4-H Special interest group (shooting sports, archery, etc.)

O 4-H Member-At-Large

O Other:

68. What 4-H activities have you participated in? Check all that apply.

O 4-H Camp

O 4-H Officers' Training

O 4-H projects/fair exhibits

O 4-H Public speaking/presentations

$\mathrm{O}$ 4-H Judging events

○ 4-H Skillathons

O Other: 
Please indicate your level of agreement with each of the following statements using $\mathrm{SD}=$ strongly disagree, $\mathrm{D}=$ disagree, $\mathrm{A}=$ agree, and $\mathrm{SA}=$ Strongly agree.

(circle one answer per statement)

\begin{tabular}{|c|c|c|c|c|c|}
\hline & & 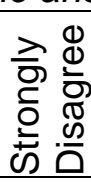 & 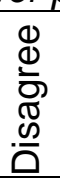 & $\begin{array}{l}\frac{\Phi}{\Phi} \\
\frac{0}{8}\end{array}$ & 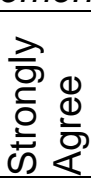 \\
\hline 69. & My participation in 4-H has helped me be successful. & $\mathrm{SD}$ & $\overline{\mathrm{D}}$ & A & SA \\
\hline 70. & 4-H has made a positive difference in my life. & SD & $\mathrm{D}$ & A & SA \\
\hline 71. & 4-H has made a positive difference in my family's life. & SD & $\mathrm{D}$ & A & SA \\
\hline 72. & $\begin{array}{l}\text { If it weren't for 4-H, there would be other organized } \\
\text { activities of interest to me outside of school time in my } \\
\text { community. }\end{array}$ & SD & $\mathrm{D}$ & A & SA \\
\hline 73. & 4-H provides a safe place for learning new materials. & SD & $\mathrm{D}$ & A & SA \\
\hline 74. & 4-H provides a safe place for me to be involved. & SD & $\mathrm{D}$ & A & SA \\
\hline 75. & 4-H clubs are a place where I feel accepted for who I am. & SD & $\mathrm{D}$ & A & SA \\
\hline 76. & In 4-H, I can explore my own interests. & SD & $\mathrm{D}$ & A & SA \\
\hline 77. & 4-H leaders made a positive difference in my life. & SD & $\mathrm{D}$ & A & SA \\
\hline 78. & I feel I could ask a 4-H leaders any question I might have. & SD & $\mathrm{D}$ & A & SA \\
\hline 79. & I feel 4-H has helped me develop leadership skills. & SD & $\mathrm{D}$ & A & SA \\
\hline 80. & I have taken on leadership roles through $4-\mathrm{H}$. & SD & $\mathrm{D}$ & $A$ & SA \\
\hline
\end{tabular}

81. What is your favorite part of $4-\mathrm{H}$ ? Please explain in the space below.

82. What is your least favorite part of $4-\mathrm{H}$ ? Please explain in the space below.

END

Thank you for completing this questionnaire! 


\section{APPENDIX C}

\section{Cover Letter to Students}




\section{WestVirginiaUniversity}

Davis College of Agriculture, Natural Resources and Design

February 6, 2012

Dear Student:

You are an important part of our community. We are interested in how you spend your time out of school and what activities you are in. We hope you will share your thoughts with us. Please take a few moments to sign the attached consent form.

I am Veronica Wilcox, a graduate student in Agricultural and Extension Education at West Virginia University. Under the direction of my advisor, Dr. Deborah A. Boone, I am conducting a research study to determine how students spend their out-of-school time and in which activities they are involved. The results of this study will be used to prepare a thesis to partially fulfill the requirements for a Master of Science Degree in Agricultural and Extension Education. By determining how students prefer to spend their out-ofschool time, we hope to be able to use the results to develop and promote programs that develop skills, abilities and confidence of youth. West Virginia University's IRB permission for this research is on file.

Participation in this research study is up to you and will be done at school the week of February 15,2012. You may skip any question you do not want to answer or you may quit at any point and turn in the survey. All answers will be held as secret as possible. No one will know which survey is yours. Survey results will be reported so your answers cannot be identified. There is no penalty if you choose not to participate.

You will need to complete, initial each page and sign the final page of the ASSENT form which is attached. You will also need to have your parent or guardian sign the CONSENT form. We must have both forms back for you to participate. Please return the signed consent form to your teacher by Friday, February 10, 2012. If you have questions, you may reach Veronica at Veronica.Wilcox@mail.wvu.edu or Dr. Debby Boone at 304293-5450 or by email at debby.boone@mail.wvu.edu. We sincerely appreciate your time and effort!

Sincerely,

Veronica R. Wilcox

Graduate Student
Deborah A. Boone, Ph.D.

Associate Professor
Phone: $304-293-5488$

Fax: 304-293-3752

www.caf.wvu.edu/resm/aee
DIVISION OF RESOURCE MANAGEMENT

Agricultural and Extension Education

2056 Agricultural Sciences Building

PO Box 6108

Morgantown, WV 26506-6108
Equal Opportunity/Affirmative Action Institution 
APPENDIX D

Cover Letter to Parents 


\section{WestVirginiaUniversity}

Davis College of Agriculture, Natural Resources and Design

February 27, 2012

Dear Parents:

Your child(ren) are an important part of our community and are the future of this state and country. We are interested in your child's perception of how they spend their out of school time and the activities in which they are involved. We request your consent for your child to participate in this study. Please take a few moments to complete the attached consent form.

I am Veronica Wilcox, a graduate student in Agricultural and Extension Education at West Virginia University. Under the direction of my advisor, Dr. Deborah A. Boone, I am conducting a research study to determine how students spend their out-of-school time and in which activities they are involved. The results of this study will be used to prepare a thesis to partially fulfill the requirements for a Master of Science Degree in Agricultural and Extension Education. By determining how students prefer to spend their out-of-school time, we hope to be able to use the results to develop and promote programs that develop the skills, abilities and confidence of youth. West Virginia University's IRB acknowledgement of this research is on file.

Participation in this research study by your child is completely voluntary. They may skip any question they are not comfortable answering or they may quit at any point and turn in a partially completed survey. All information will be held as confidential as possible. The students will not be identified with the surveys in any manner. Survey results will be reported in a summary format and individual responses will not be identifiable. There will be no penalty or services withheld if you do not allow your child to participate.

Thank you in advance for providing consent for your child to participate in this research effort! Please return the signed consent form, your child's assent form and the completed survey to your child's teacher by Friday, March 9,2012. If you have questions, you may reach Veronica at Veronica.Wilcox@mail.wvu.edu or Dr. Debby Boone at 304-293-5450 or by email at debby.boone@mail.wvu.edu. We sincerely appreciate your time and effort!

Sincerely,

Veronica R. Wilcox

Graduate Student
Deborah A. Boone, Ph.D. Associate Professor
DIVISION OF RESOURCE MANAGEMENT

Agricultural and Extension Education

2056 Agricultural Sciences Building

PO Box 6108

Morgantown, WV 26506-6108 


\section{APPENDIX E}

Instructions to Student and Parents 


\section{Instruction Sheet}

\section{Tyler County $5^{\text {th }}, 7^{\text {th }} \& 9^{\text {th }}$ graders}

1. Read the Student cover letter

2. Give your parents the Parent cover letter and CONSENT forms (pink forms)

3. Get permission from your parents to participate in the study

4. Complete the ASSENT form (yellow form) (initial page 1and sign page 2)

5. Complete the questionnaire

6. Collect the questionnaire, ASSENT (yellow), and CONSENT (pink) forms

7. Place the three items in the manila envelope and return to your teacher by March 9, 2012

\section{Parents of Tyler County $5^{\text {th }}, 7^{\text {th }} \& 9^{\text {th }}$ graders}

1. Read the Parent cover letter

2. Give your son/daughter permission to complete the questionnaire

8. Sign one copy of the CONSENT form (pink form) (initial pages $1 \& 2$ and sign page 3)

3. Return one signed copy of the CONSENT form (pink form) in the completed packet to your child's teacher

4. Keep a copy of the CONSENT form (pink form) for your records.

9. Assist your son/daughter with returning the questionnaire, ASSENT (yellow), and CONSENT (pink) forms in the manila envelope and return to your child's teacher by March 9, 2012.

Thank you very much for allowing your son/daughter to participate in this research study. 


\section{APPENDIX F}

Student Assent Form 


\section{W- WestlirginiaUniversity \\ Office of Research Compliance}

\section{ASSENT FORM}

OMR-Assent

Principal Investigator: Boone, Deborah

Department: $\quad$ AGRICULTURE \& FORESTRY - Resource Management Tracking Number: $\quad \mathrm{H}-23754$

\section{Study Title:}

Out of School Time Study

Co-Investigator(s):

Wilcox, Veronica,

\section{Sponsor}

\section{Contact Persons}

If you have any questions, concerns, or complaints about this research, you can contact Dr. Debby Boone at (304) 293-5450 or email her at Debby.Boone@mail.wvu.edu

For information regarding your rights as a research subject, you may contact the Office of Research Compliance at 304/293-7073.

\section{Introduction}

In addition if you would like to discuss problems, concerns, have suggestions related to research, or would like to offer input about the research, contact the Office of Research Integrity and Compliance at 304293-7073.

You have been asked to be in this research study, which has been explained to you by Veronica Wilcox and Dr. Deborah Boone in the cover letter.

\begin{tabular}{lllll}
\hline Tracking \#: & $\mathrm{H}-23754$ & Page 1 of 2 & \\
Approved On: & $02 / 17 / 2012$ & & Initials & \\
Valid Through: & $02 / 16 / 2013$ & & \\
Last Amended: & $\mathrm{N} / \mathrm{A}$ & &
\end{tabular}


Tracking \#: $\quad \mathrm{H}-23754$

\section{Purposes of the Study}

You have been told that the purpose of this research study is to learn more about how 5, 7 \& 9th grade students spend their out of school time.

\section{Description of Procedures}

This research study will be done at all Tyler County Schools with grades 5 , $7 \& 9$, during the school day. You will be asked to complete a series of questions on how you spend your out of school time and in what activities you participate. It will take about 30 minutes for you to answer the questions. You do not have to answer all of the questions.

\section{Discomforts}

Some of the questions may be difficult and you may not enjoy trying to answer them.

\section{Benefits}

This research study may not help you, but what they learn from the study may help other people.

\section{Confidentiality}

We promise that anything we learn about you in this research study will be kept as secret as possible.

\section{Voluntary Participation}

You do not have to do this. No one will be mad at you if you refuse to do this or if you decide to quit. You have been allowed to ask questions about the research study, and all of your questions were answered.

\begin{tabular}{|c|c|c|}
\hline Tracking \#: & $\mathrm{H}-23754$ & Page \\
\hline Approved On: & $02 / 17 / 2012$ & \\
\hline Valid Through: & $02 / 16 / 2013$ & \\
\hline Last Amended: & N/A & \\
\hline
\end{tabular}


Tracking \#:

$\mathrm{H}-23754$

I willingly agree to be in this research.

Signature of Subject

Printed Name

Date

Time

\begin{tabular}{lll}
\hline Tracking \#: & $\mathrm{H}-23754$ & Page 3 of 3 \\
Approved On: & $02 / 17 / 2012$ & \\
Valid Through: & $02 / 16 / 2013$ & \\
Last Amended: & N/A &
\end{tabular}


APPENDIX G

Parental Consent Form 


\title{
W. WestVirginiaUniversity. \\ Office of Research Compliance
}

\section{PARENTAL OR GUARDIAN CONSENT AND INFORMATION FORM}

OMR-Parental Consent

\author{
Principal Investigator: Boone, Deborah \\ Department: $\quad$ AGRICULTURE \& FORESTRY - Resource Management \\ Tracking Number: $\mathrm{H}-23754$ \\ Study Title: \\ Out of School Time Study
}

Co-Investigator(s):

Wilcox, Veronica,

Sponsor

Not applicable

\section{Contact Persons}

If you have any questions, concerns, or complaints about this research study, you can contact Dr. Deborah Boone at 304/yy293-5450.

For information regarding your rights as a research subject, you may contact the Office of Research Compliance at 304/293-7073.

\section{Introduction}

You have been asked to allow your child to participate in this research study, which has been explained to you and your child by Veronica Wilcox and Dr. Deborah Boone, in the cover letter. This study is being conducted by Veronica Wilcox and Dr. Deborah Boone at West Virginia University in the Department of Agricultural \& Extension Education. This research is being conducted to fulfill the requirements for a a master's thesis in the Department of Agricultural \& Extension Education at West Virginia University, under the supervision of Deborah A. Boone, Ph.D.

Purposes of the Study

\begin{tabular}{lllll}
\hline Tracking \#: & $\mathrm{H}-23754$ & Page & 1 of 3 & \\
Approved On: & $02 / 17 / 2012$ & & & \\
Valid Through: & $02 / 16 / 2013$ & & & \\
Last Amended: & $\mathrm{N} / \mathrm{A}$ & & &
\end{tabular}


Tracking \#: $\quad \mathrm{H}-23754$

The purpose of this research study is to learn more about how $5,7 \& 9$ th grade students spend their out of school time. WVU expects approximately 301 persons to participate in this research study.

\section{Description of Procedures}

This research study involves a series of questions on how students spend their out of school time and will take approximately 30 minutes for your child to complete. Your child will be asked to fill out a questionnaire regarding how they spend their out of school time and in what activities they are involved. This will take approximately 30 minutes to complete. Your child does not have to answer all the questions.

You will have the opportunity to see the questionnaire before signing this consent form. The research study will be performed at all Tyler County Schools with grades 5, $7 \&$ 9. Approximately 300 subjects are expected to participate in this study.

\section{Risks and Discomforts}

There are no known or expected risks to your child from participating in this research study, except for the mild frustration associated with answering the questions.

\section{Alternatives}

Your child does not have to participate in this study.

\section{Benefits}

Your child may not receive any direct benefit from this research study. The knowledge gained from this research study may eventually benefit others.

Financial Considerations

No payments will be made for participating in the research study.

\section{Confidentiality}

Any information about your child that is obtained as a result of participation in this research will be kept as confidential as legally possible.

\begin{tabular}{lllll}
\hline Tracking \#: & $\mathrm{H}-23754$ & Page & 2 of 3 & \\
Approved On: & $02 / 17 / 2012$ & & Initials & \\
Valid Through: & $02 / 16 / 2013$ & & \\
Last Amended: & N/A & & &
\end{tabular}


Any research records, may be subpoenaed by court order or may be inspected by federal regulatory authorities without your additional consent.

In any publications that result from this research, neither your child's name nor any information from which your child might be identified will be published without your consent.

Voluntary Participation

Participation in this research study is voluntary.

You or your child may refuse to participate in this research study. You or your child may withdraw from this research study at any time.

Refusal to participate or withdrawal will not affect your child 's future opportunities and will involve no penalty to you or your child.

\section{Statement of Parent/Guardian:}

My child appears to understand the research to the best of his or her ability and has agreed to participate.

\begin{tabular}{llll}
\hline Tracking \#: & $\mathrm{H}-23754$ & Page & 3 of 3 \\
Approved On: & $02 / 17 / 2012$ & & \\
Valid Through: & $02 / 16 / 2013$ & \\
Last Amended: & N/A &
\end{tabular}


Sign this form, keep second copy for your files.

I willingly consent to allow my child to participate in this research.

Signature of Parent or Guardian

Printed Name

$\overline{\text { Date }} \overline{\text { Time }}$

The parent/guardian has had the opportunity to have questions addressed. The parent/guardian willingly agrees to allow his/her child to be in the study.

Signature of Investigator or

Printed Name

Date

Time

Co-Investigator

Tracking \#:

Approved On:

Valid Through:

Last Amended
H-23754

02/17/2012

$02 / 16 / 2013$

N/A
Page 4 of 4

Initials

Date 


\section{APPENDIX H}

\section{Purposes of Questions}


Purposes of Questions

1. Extracurricular participation

2. Extracurricular participation

3. Extracurricular participation

4. Extracurricular participation

5. Extracurricular participation

6. Extracurricular participation

7. Friends

8. Physical activity

9. Negative behaviors

10. Negative behaviors

11. Caring about others

12. Caring about others

13. Caring about others

14. Contact with adults

15. Contact with adults

16. Contact with adults

17. Self confidence

18. Skills Learned

19. Positive identity - personal power

20. Positive identity -self esteem

21. Positive identity -self esteem
22. Empowerment

23. Positive identity -self esteem

24. Positive identity -sense of purpose

25. Social competencyinterpersonal competency

26. Social competencyinterpersonal competency

27. Social competencyinterpersonal competency

28. Empowerment

29. Resistance

30. Social competency-leadership

31. Social competency-leadership

32. Social competency-leadership

33. Social competency-planning \& decision making

34. Social competency-leadership

35. Social competency-leadership

36. Positive identity - personal

power

37. Social competency - planning 
38. Self confidence - resistance skills

39. Character

40. Empowerment

41. Resistance

42. Empowerment

43. Empowerment

44. Social competency interpersonal competence

45. Empowerment

46. Empowerment

47. Social competency - planning \& decision making

48. Skills learned

49. Skills learned

50. Skills learned

51. Contact with adults

52. Contact with adults

53. Contact with adults

54. Social competency resistance skills

55. Skills learned

56. Empowerment
57. Social competency leadership

58. Social competency leadership

59. Age

60. Grade

61. Gender

62. Location

63. Grades

64. Ever been a 4-H member

65. Years in 4-H

66. Current 4-H member

67.4-H club type

68.4-H activities

69. Impact of 4-H

70. Impact of 4-H

71. Impact of 4-H

72. Impact of 4-H

73. Impact of 4-H

74. Impact of 4-H

75. Impact of 4-H

76. Impact of 4-H

77. Impact of 4-H 
78. Impact of 4-H

79. Impact of $4-\mathrm{H}$

80. Impact of $4-\mathrm{H}$

81. Impact of $4-\mathrm{H}$

82. Impact of $4-\mathrm{H}$ 


\section{APPENDIX I}

Out of School Time Survey Responses to Questions with Other 


\title{
Out of School Time Survey Questions with Other
}

Q57. Which of the following leadership roles have you held in school in the past year?

\author{
Other Listed: \\ Math Field Day \\ Group Time Leader \\ Student Council \\ Tudor \\ Team Captain \\ Volleyball \& Basketball Team Captain \\ Student Council \\ Student Council
}

8

Q58. Which of the following leadership roles have you held out of school in the past year?

Other Listed:

Community Service

Pledge

Sports

Volunteer of Energy Express

Assistant Coach League Sports

Scouts - Assistant Patrol Leader

Student Council 
Q68G.What 4- $\mathrm{H}$ activities have you participated in?

Hiking, Art, Fishing, Dance 


\section{VERONICA R. WILCOX}

Home: PO Box 3, Shirley, West Virginia 26434 veronica.wilcox@mail.wvu.edu (304) 288-3963 Office: WVU Extension Tyler County, 311 Main Street, Middlebourne, WV 26434 (304) 758-2101

\section{Education}

\section{Masters of Science: Agriculture and Extension Education}

West Virginia University, Morgantown West Virginia

\section{Bachelor of Arts: International Studies}

Ohio State University, Columbus Ohio

\section{The Ohio State University Leadership, Education and Development Program}

The OSU LEAD Program focuses on leadership and media training, state and national political processes, economic viability, environmental capability and poverty and family issues. Participants are nominated based on their previous leadership activities, communication skills, character and commitment to bringing about change in Ohio's communities.

\section{Professional Experience}

Agent in Training, Interim Extension Agent, County Program Coordinator, Visiting Faculty

WVU Extension Service, Doddridge, Preston, Marion \& Tyler Counties, 2009 - August 2012

Distance Learning Coordinator, Sojourners Care Network/Youthbuild, 2008 - 2009

Events Coordinator (interim), Ohio University Alumni Association, Summer 2008

Field Executive, Girl Scouts, 2006 - 2008

Associate: Office management, web development, computer support and program coordination The Ohio State University Extension, 1999 - 2006

Campground Coordinator, Ohio Department of Natural Resources: Hocking Hills State Park, 1994 - 1999

Program Director, YMCA, 1988-1990

\section{Academic Appointment}

- $\quad$ Agent in Training 2009 
- Interim Extension Agent 2011

- County Program Coordinator 2012

- Visiting Instructor/Faculty since 2009

\section{Teaching Experience}

(Invites)

- Venison How To Present publication (Peer Review State \& National, 2012)

- Venison 101 Train the Trainer (Peer Review State, 2011)

- Venison Workshops in Harrison County, Preston County, and Boone County WV (Peer Review State, 2010-2011)

- Venison Presentation at WVU Employeefest, 2011

- National 4-H Conference, Global Education Team (Peer Review State \& National, 2010)

- Delegation of teachers \& principal from Mexico (Peer Review State \& International, 2010)

\section{Research Publications}

- Wilcox, V.R. 2012. Venison Fact Sheet Series. West Virginia University Extension Service.

- Wilcox, V.R. 2012. Global Education Skillathon Gestures. West Virginia University Extension Service.

- Wilcox, V.R. 2012. Tie Dye Skillathon. West Virginia University Extension Service.

- Wilcox, V.R. 2012. Global Education Skillathon. West Virginia University Extension Service.

- Nix, K. \& et al. 2011. Building Leadership and Teams Facilitator Resource Guide. West Virginia University Extension Service.

- Wilcox, V.R. August 2010. Around Our State. West Virginia Farm Bureau News. pg. 10

- Wilcox, V.R. August 2010. Treat Deer as Food from Field to Table. West Virginia Farm Bureau News. pg. 11

\section{Research Presentations}

- Wilcox, V.R. \& Global Education Team. October 2010. NAE4-HA presentation

- Inreach - Global Education Curriculum presented

- Outreach - Global Education on Chili and Mexico

\section{Service}


- WVU Extension Service, County Program Coordinator, Tyler County (2012)

- National Camping Institute, Finance Committee Co-Chair (2012)

- WVU Global Education Team (2009-present)

- Advisor to 4-H Charters, Tyler County (2011-2012)

- 4-H Leaders' Association, Tyler County (2011-2012)

- Advisor to 4-H Teen Leaders, Tyler County (2011-2012)

- Calf Pool, Tyler County (2011-2012)

- Master Gardeners, Tyler County (2011-2012)

- Emergency Management Association, Tyler County (2011-2012)

- Board of Education, Tyler County (2011-2012)

- 4-H \& Farm Committee, Tyler County (2011-2012)

- Fairboard, Tyler County (2011-2012)

- Farm Bureau, Tyler County (2011-2012)

- Buckwheat Festival Arts \& Crafts Committee (2010-2011)

- Farm Service Agency, Preston County (2010)

- Farmland Preservation Committee, Preston County (2010)

- Buckwheat Festival Judge (2010)

- 4-H Resident Camp Counselor and Program Presenter (2000-present)

- 4-H Project Interview Judge (2005-2010)

- Advisor to 4-H Junior Leaders and Junior Fairboard (2001-2009)

- Provide annual lifeguard training and testing for camp staff at Canter's Cave, Ohio (2003 - 2011)

- Elected member of the Vinton County 4-H Executive Board and Council (2006 2008)

- Coordinated grass roots campaign resulting in passage of a levy enabling county extension office to be reopened with expanded hours, programming, staff and budget (2006)

\section{Honors \& Awards}

- National Association of Extension 4-H Agents National Excellence in Global Citizenship Programming Award for the Global Education Team 2012

- National Association of Extension 4-H Agents Northeast Region Excellence in Global Citizenship Programming for the Global Education Team 2012

- National Association of Extension 4-H Agents Northeast Region Excellence in Teamwork Award for the Global Education Team 2011

- West Virginia Association of Extension 4-H Agents Team Excellence Award 2011

- Family and Consumer Science Award for Teamwork in Venison 2011

- WVU Extension Award of Excellence: Team Program Excellence for the WVU Extension Service Global Education Team 2010

- WVU 2010 Webby Award: Honorable Mention, Doddridge County

\section{Grants}


- Wilcox, V.R. 2012. 4-H \& Farm Association. \$10,000 from Governor's Award

- Wilcox, V.R. 2012. 4-H Leaders' Association. \$2,000 from Little Kanaugh

- Wilcox, V.R. 2012. Energy Express. \$500 from WVU Share Our Strength

- Wilcox, V.R. 2012. Energy Express. \$2,500 from Staley Green

- Wilcox, V.R. 2012. Energy Express. \$5,000 from Sisters of St. Joseph

- Wilcox, V.R. 2012. Energy Express. \$5,000 from the Bernard McDunough/Walmart Grant

- Wilcox, V.R. 2010. Faculty Professional Development. \$500 from West Virginia University

- Wilcox, V.R. 2010. Faculty Professional Development. \$100 from WVAE4H

- Wilcox, V.R. 2010. Smokeless Tobacco Cessation.\$1500 from the Regional Tobacco Prevention Coalition through the Marion County Health Department to educate little league coaches to support tobacco prevention and prevent smokeless tobacco use in little league baseball

- Wilcox, V.R. 1989. Facilities Improvement Grant. $\$ 60,000$ in grants and fundraising for facility improvements that enabled expansion of use from summer to year round activities.

\section{Certifications}

ATV Safety Institute E-Course and Rider Course, WVU Driver's Safety Training, Procard, First Aid and CPR, Water Safety Instructor, Lifeguard Training Instructor, Swim Coach Clinic Instructor, Swim Instructor for all levels and ages, National Pool and Spa Operator, Swim Coach, Scuba Diver, Skydiver

Visiting Faculty, Extension Agent in Training/Interim Agent, West Virginia University Extension, Davis College, Tyler County 